\title{
Flavonoids: A complementary approach to conventional therapy of COVID-19?
}

\author{
Julia Solnier (1D) Johannes-Paul Fladerer
}

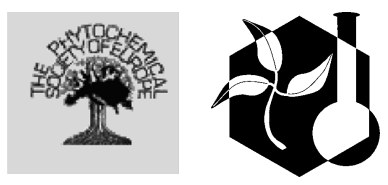

Received: 21 April 2020/Accepted: 29 August 2020/Published online: 18 September 2020

(C) The Author(s) 2020

\begin{abstract}
COVID-19, the highly contagious novel disease caused by SARS-CoV-2, has become a major international concern as it has spread quickly all over the globe. However, scientific knowledge and therapeutic treatment options for this new coronavirus remain limited. Although previous outbreaks of human coronaviruses (CoVs) such as SARS and MERS stimulated research, there are, to date, no antiviral therapeutics available that specifically target these kinds of viruses. Natural compounds with a great diversity of chemical structures may provide an alternative approach for the discovery of new antivirals. In fact, numerous flavonoids were found to have antiviral effects against SARS-and MERS-CoV by mainly inhibiting the enzymes 3-chymotrypsin-like protease (3CLpro) and papain-like protease (PLpro). In this review, we specifically focused on the search for flavonoids, polyphenolic compounds, which are proven to be effective against human CoVs. We therefore summarized and analyzed the latest progress in research to identify flavonoids for antiviral therapy and proposed strategies for future work on medicinal plants against coronaviruses such as SARS-CoV-2. We discovered quercetin, herbacetin, and
\end{abstract}

J. Solnier $(\square) \cdot$ J.-P. Fladerer

Institute of Pharmaceutical Sciences, Department of Pharmacognosy, University of Graz, Universitätsplatz 4, 8010 Graz, Austria

e-mail: julia.solnier@uni-graz.at isobavachalcone as the most promising flavonoids with anti-CoV potential.

Keywords Flavonoids - Coronaviruses · Positivesense RNA viruses · COVID-19 · SARS-CoV · SARSCoV-2 - MERS-CoV

\section{Introduction}

Historically, viral diseases have always emerged and posed major issues to public health. Several viral outbreaks - such as the severe acute respiratory syndrome coronavirus (SARS-CoV) in 2002-2003, the H1N1 influenza virus in 2009, and the Middle East respiratory syndrome coronavirus (MERS-CoV) in 2012 - have caused serious global health concerns in recent years (Cascella et al. 2020). Over the past 50 years, there has been a noticeable increase in the emergence of different novel coronaviruses responsible for a wide range of human and veterinary diseases (Fehr and Perlman 2015). Most recently, a new viral epidemic with numerous cases of unexplained low respiratory tract infections occured in Wuhan, Hubei Province, China, as it was first reported to the World Health Organization (WHO) on 31 December 2019 (World Health Organization 2020b). The novel virus strain was identified as the Severe Acute Respiratory Syndrome Coronavirus 2 (SARS-CoV-2) triggering 
coronavirus disease 2019 (COVID-19) (He et al. 2020a). On 11 March 2020, the WHO declared COVID-19 a pandemic (World Health Organization 2020a).

Coronaviruses (CoVs) are highly diverse, enveloped, positive-sense, single-stranded RNA viruses (+ ssRNA) (He et al. 2020a), which constitute the biggest group of viruses within the Nidovirales order, containing the largest genomes for RNA viruses (Fehr and Perlman 2015).

In total, about $30 \mathrm{CoVs}$ have so far been recognized to be able to infect different species, including humans, mammals, fowl, and other animals ( $\mathrm{Li}$ et al. 2020). Among them, seven human CoVs, belonging to the alpha- and beta-CoVs groups ( $\mathrm{Li}$ et al. 2020), have been identified as being capable of infecting humans, including 229E, NL63, OC43 HKU1, MERS$\mathrm{CoV}$, SARS-CoV and the novel SARS-CoV-2 (Centers for Disease Control and Prevention 2020; Fehr and Perlman 2015; Zhu et al. 2020). The name 'coronavirus' is inspired by its most defining feature: the club-shaped spikes projecting from the surface of the virion. The spikes sticking out of the envelope's surface give the virus the appearance of a crown (Fehr and Perlman 2015).

The nucleocapsids of CoVs, enclosing the genomic RNA, are helically symmetrical. This is in fact unusual for positive-sense RNA viruses, and far more common for negative-sense RNA viruses (Fehr and Perlman 2015). The two overlapping open-reading-frames (ORF1a and ORF1b) of SARS, translated into the viral enzymes 3C-like protease (3CLpro) and papainlike protease (PLpro), which are vital for virus multiplication, constitute approximately two-thirds of the genome (Adedeji et al. 2012). The other onethird of the genome encodes structural proteins of the virus, such as the spike (S), envelope (E), membrane (M) and nucleocapsid (N) proteins (Adedeji et al. 2012). The interaction between the S-protein and the receptor is the primary determinant for a coronavirus to infect a host species (Lim et al. 2016). To date, it is known that SARS-CoV attaches to its receptor angiotensin-converting enzyme 2 (ACE2), while MERS-CoV was found to bind to dipeptidyl-peptidase 4 (DPP4) in order to penetrate human cells (Fehr and Perlman 2015). So far, it has been observed that the new coronavirus SARS-CoV-2 behaves much like SARS by using the same entry mechanism to human cells (Rabi et al. 2020) and sharing a 79.5\% genome sequence identity to SARS-CoV (Yang et al. 2020; Zhou et al. 2020). Several studies have demonstrated that novel SARS-CoV-2 likely binds to the human ACE2 receptor, but with a higher affinity than the original SARS virus strain (Gurwitz 2020; Letko et al. 2020; Rabi et al. 2020; Wrapp et al. 2020; Xu et al. 2020).

Genetic data demonstrated that SARS-CoV-2 possesses overlapping open-reading-frames (ORF1a and ORF1b) similar to those of SARS- and MERS-CoV (Fig. 1), translated into the viral enzymes 3CLpro and PLpro. SARS- and SARS-CoV-2 share a 3CLpro sequence similarity of $96 \%$, and a PLpro sequence identity of $83 \%$ (McKee et al. 2020). Therefore, 3CLpro and PLpro present two key targets for the development of anti-SARS-CoV-2 therapeutics as both are crucial for viral replication; and they share significant homology with proteases of several other related coronaviruses (Goetz et al. 2007).

\section{Therapeutic approach}

Even though the SARS and MERS outbreaks stimulated research on human CoVs, there are, to date, no antiviral therapeutics available that specifically target these viruses (Rabaan et al. 2020). Several potential vaccines, including recombinant attenuated viruses, live virus vectors, or individual viral proteins expressed from DNA plasmids, have been developed for SARS-CoV; however, none of them are yet approved for clinical use (Fehr and Perlman 2015). There are several reports which propose potential drugs, although their clinical efficacy has not yet been confirmed for SARS-CoV-2 infection and COVID-19 disease. These drugs include: chloroquine, lopinavir/ ritonavir, remdesivir, umifenovir, nucleoside analogs, neuraminidase inhibitors, DNA synthesis inhibitors (e.g. tenofovir disoproxil, and lamivudine), ACE2based peptides, novel vinylsulfone protease inhibitors, teicoplanin, 3-chymotrypsin-like protease (3CLpro)and papain-like protease (PLpro) inhibitors (Lai et al. 2020; McKee et al. 2020). To date, the application of remdesivir appears to be the most promising strategy for COVID-19 (Lai et al. 2020). In preclinical studies, it has been shown that remdesivir (GS5734) —an inhibitor of RNA polymerase with in-vitro activity which was used against various RNA viruses, including Ebola—could be effective for both prophylaxis 


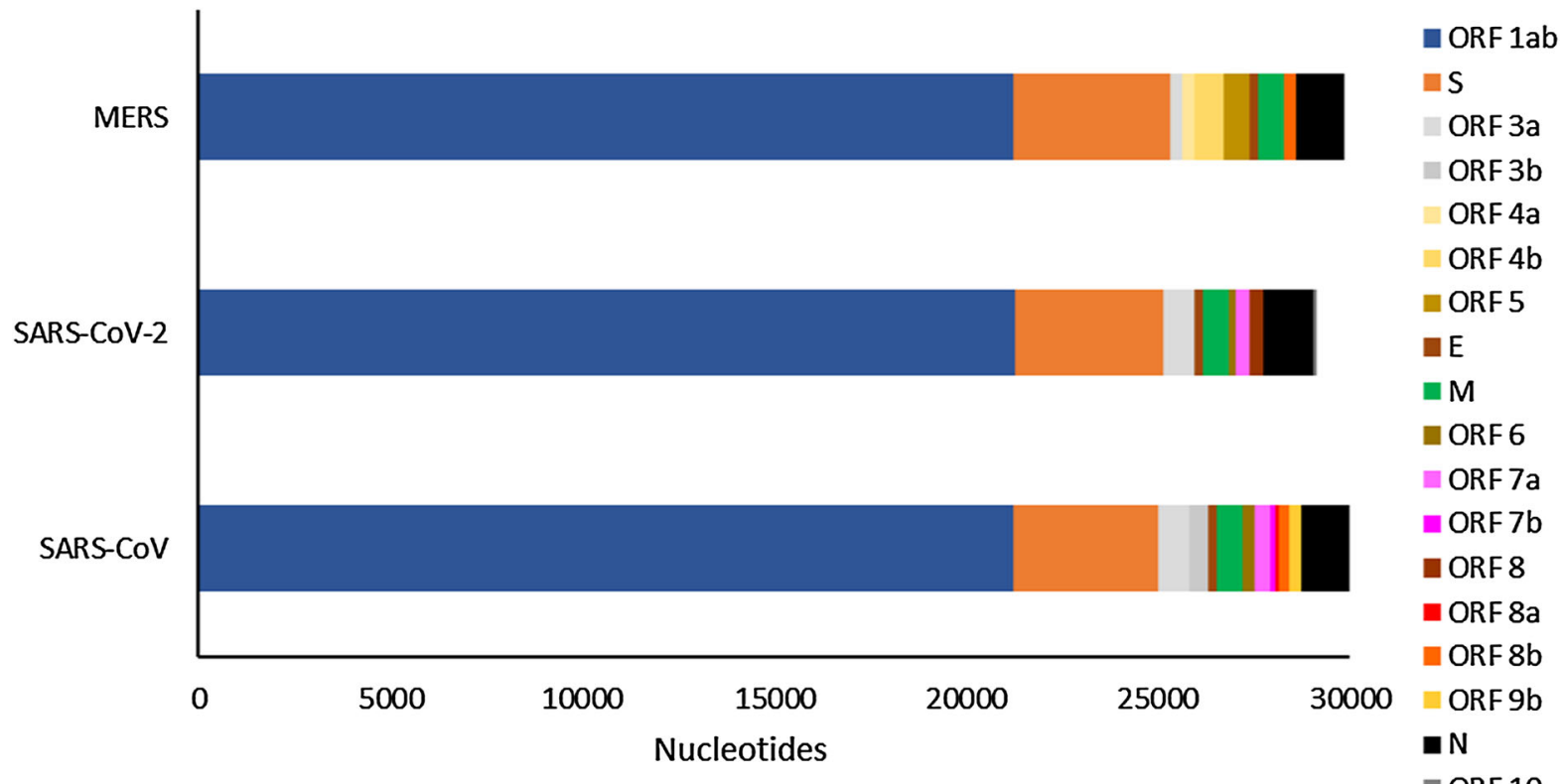

Fig. 1 Comparison of the genomic structures of MERS, SARS$\mathrm{CoV}$ and SARS-CoV-2. The data are extracted from the original publications in GenBank. Especially SARS-CoV and SARS-

and therapy against human $\mathrm{CoV}$ infections (Gordon et al. 2020). Alpha-interferon and lopinavir/ritonavir have also been suggested for the treatment of CoVs (Cascella et al. 2020).

\section{Flavonoids and their antiviral potential against coronaviruses}

Since therapy options for coronaviruses, such as for COVID-19, comprise only preventive and supportive measures, natural products may have a fundamental role in supportive and prophylaxis treatments, and present an alternative approach for $\mathrm{CoV}$-management. Flavonoids form the largest group of polyphenolic compounds in higher plants (Nileeka Balasuriya and Vasantha Rupasinghe 2011), with more than 9000 structures identified (Wang et al. 2018). They represent an important class of plant secondary metabolites, widely distributed throughout the plant kingdom (Wang et al. 2018).

Flavonoids are categorised into several subgroups, which include chalcones, flavanes, flavanols, flavanones, flavanonols, flavones, flavonols, isoflavones or catechins, and procyanidins, all of them consisting
CoV-2 show high similarity. ORF = open-reading-frame; spike $(\mathrm{S})$, envelope $(\mathrm{E})$, membrane $(\mathrm{M})$ and nucleocapsid $(\mathrm{N})$ proteins

of a common flavan (2-phenylchroman) basic structure (Fig. 2). These polyphenolic substrates perform a series of protective functions in the human body. Many of them are bioactive compounds capable of interfering with nucleic acid or proteins, meaning that they have diverse pharmacological properties (Panche et al. 2016). It has been reported that flavones and catechins appear to be the most powerful antioxidants, preventing the effects of reactive oxygen species in the body (Nijveldt et al. 2001; Panche et al. 2016). There are numerous studies highlighting the broad range of biological activities of flavonoids, including antioxidant (D'Amelia et al. 2018), anti-cancer (LeJeune et al. 2015), antimicrobial (Abreu et al. 2017; Solnier et al. 2020), antiviral (Wang et al. 1998), and antiinflammatory (Catarino et al. 2016) activities (Panche et al. 2016).

More importantly, various flavonoids have been found to inhibit different targets of coronaviruses SARS and MERS (Yang et al. 2020), such as blocking the enzymatic activites of viral proteases like 3-chymotrypsin-like protease (3CLpro), papain-like protease (PLpro) and helicase or interfering with spike (S) proteins. A few flavonoids were shown to suppress the activity of angiotensin-converting enzyme (ACE) 


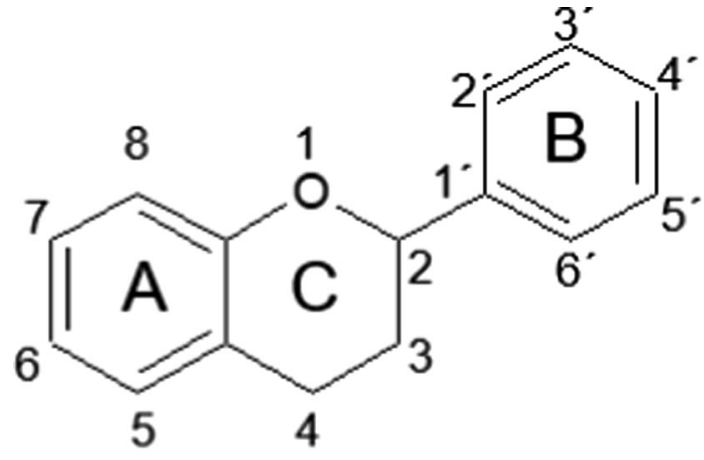

Fig. 2 Flavan structure

(Guerrero et al. 2012; Nileeka Balasuriya and Vasantha Rupasinghe 2011), which not only plays an important role in cardiovascular diseases such as in hypertension, but may also represent a key determinant in viral infections, and pneumonia (Actis-Goretta et al. 2006).

Another important issue presents the anti-inflammatory potential of flavonoids in viral diseases, such as activating and stimulating the host immune response to viral infections (Dong et al. 2014), but also suppressing overwhelming inflammatory reactions, which are often associated with a higher mortality rate of SARS-CoV-2 infections (McKee et al. 2020). For instance, some flavonoids have been reported to interfere with the activation of NLRP3 inflammasome (Lim et al. 2018) which upregulates the production of inflammatory cytokines, and thus can cause respiratory distress syndrome that frequently occurs within SARS coronavirus diseases (Chen et al. 2019), and SARS-CoV-2 infections (Shah 2020).

However, most studies on flavonoids-showing their numerous health-beneficial properties - are conducted in vitro based on the fact that these polyphenolic compounds often deal with low bioavailability, little stability and poor distribution when tested in vivo using animal and/or human cell models (Nileeka Balasuriya and Vasantha Rupasinghe 2011). There are different strategies reported to enhance these functions, such as the introduction of structural modifications (Srinivas 2009), absorption enhancers or nanotechnology (Ajazuddin and Saraf 2010; Zhao et al. 2019).

The aim of this review is to evaluate the information on flavonoids as possible leads for developing therapeutics to treat SARS-CoV-2. Therefore, we searched PUBMED for studies reporting on the effects of flavonoids on human coronaviruses. Most of the studies targeted the enzymatic activities of the viral proteases 3CL and PL in vitro using FRET (fluorescence resonance energy transfer)-based methods. $3 \mathrm{CL}$ and PL proteases represent valuable targets for the development of anti-coronaviral drugs, as these proteins are essential for the viral transcription and replication complex of all coronaviruses (Anand et al. 2003; Chen et al. 2005b; Park et al. 2016), translated from two open reading frames ORF1a and ORF1b which are found in SARS-, SARS-2-, and MERS-CoV (Chuck et al. 2011; Lin et al. 2004). According to the literature, we were able to identify 47 flavonoids which might present potential agents to treat SARSCoV-2 (Table 1). Detailed analysis of their structureactivity relationships, has ultimately led to the identification of the three most promising compounds with broad-spectrum antiviral activity.

\section{Major targets of flavonoids against CoVs}

The various studies have focused primarily on the interference of flavonoids with some viral proteases such as 3CL and PL of SARS- and MERS-CoV by using common enzymatic, fluorogenic (FRET)-based methods and molecular docking studies, as summarized in Table 2. 3CLpro and PLpro are both key targets as they process several viral polyproteins which are involved in the replication and transcription of the genomic RNA within host cells (McKee et al. 2020). Further, they share significant homology with viral proteases of several other coronaviruses-especially with those of SARS-, SARS-2-, and MERSCoV (Wu et al. 2020).

Besides 3CL protease, papain-like protease has been the focus of numerous studies on the development of chemotherapeutic drugs against $\mathrm{CoV}$-induced diseases. PLpro is not only responsible for processing viral polyproteins, but is also involved in deubiquitination (cleaving ubiquitin chains) and deISGylation, which represent relevant factors in the host immune response to viruses (Cho et al. 2013). By removing ubiquitin and ISG15 proteins from host cell proteins, the innate host immune response is likely to be compromised (Ratia et al. 2014; Xian et al. 2020). PLpro of both SARS- and MERS-CoV has been shown to possess deubiquitinating activities (Park 


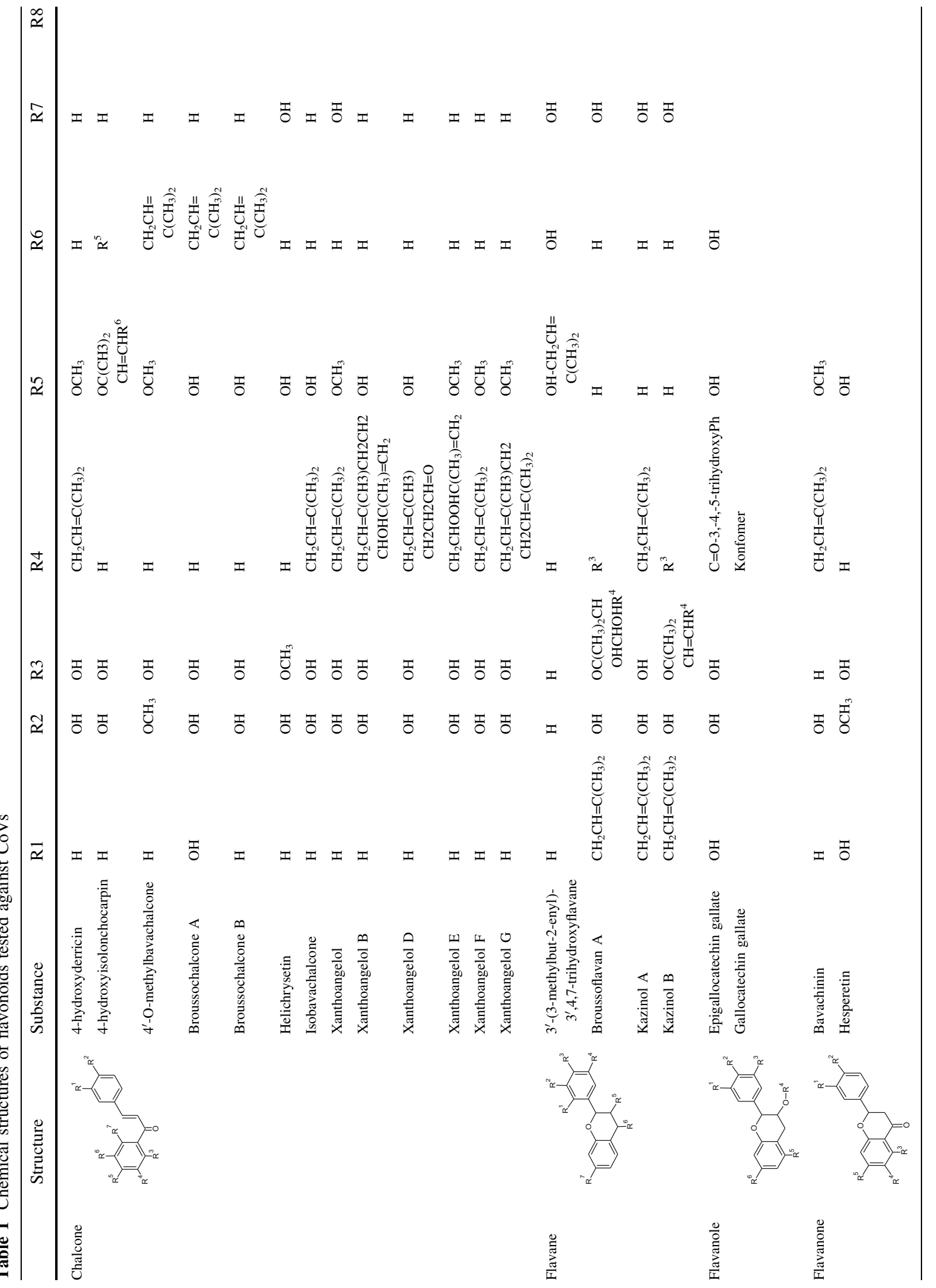




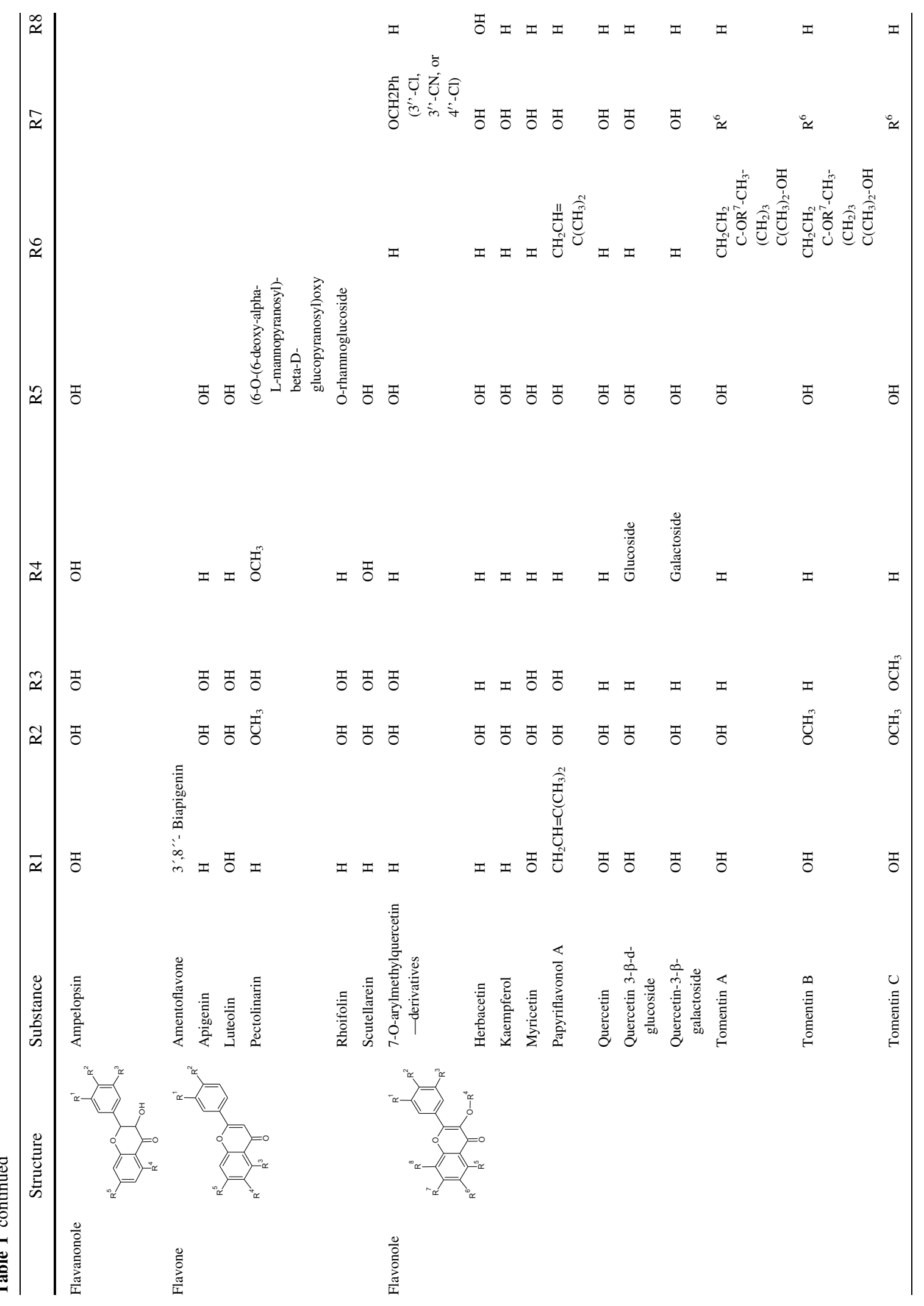




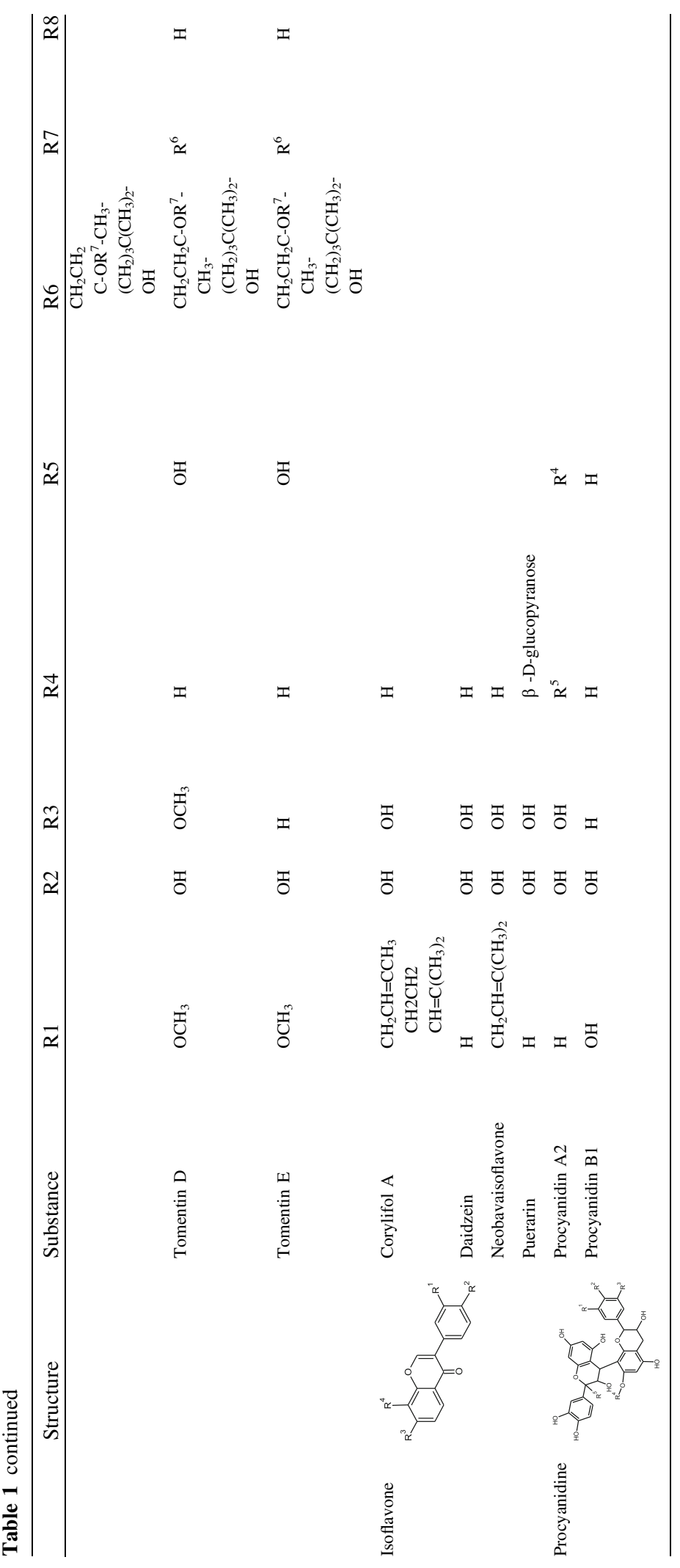




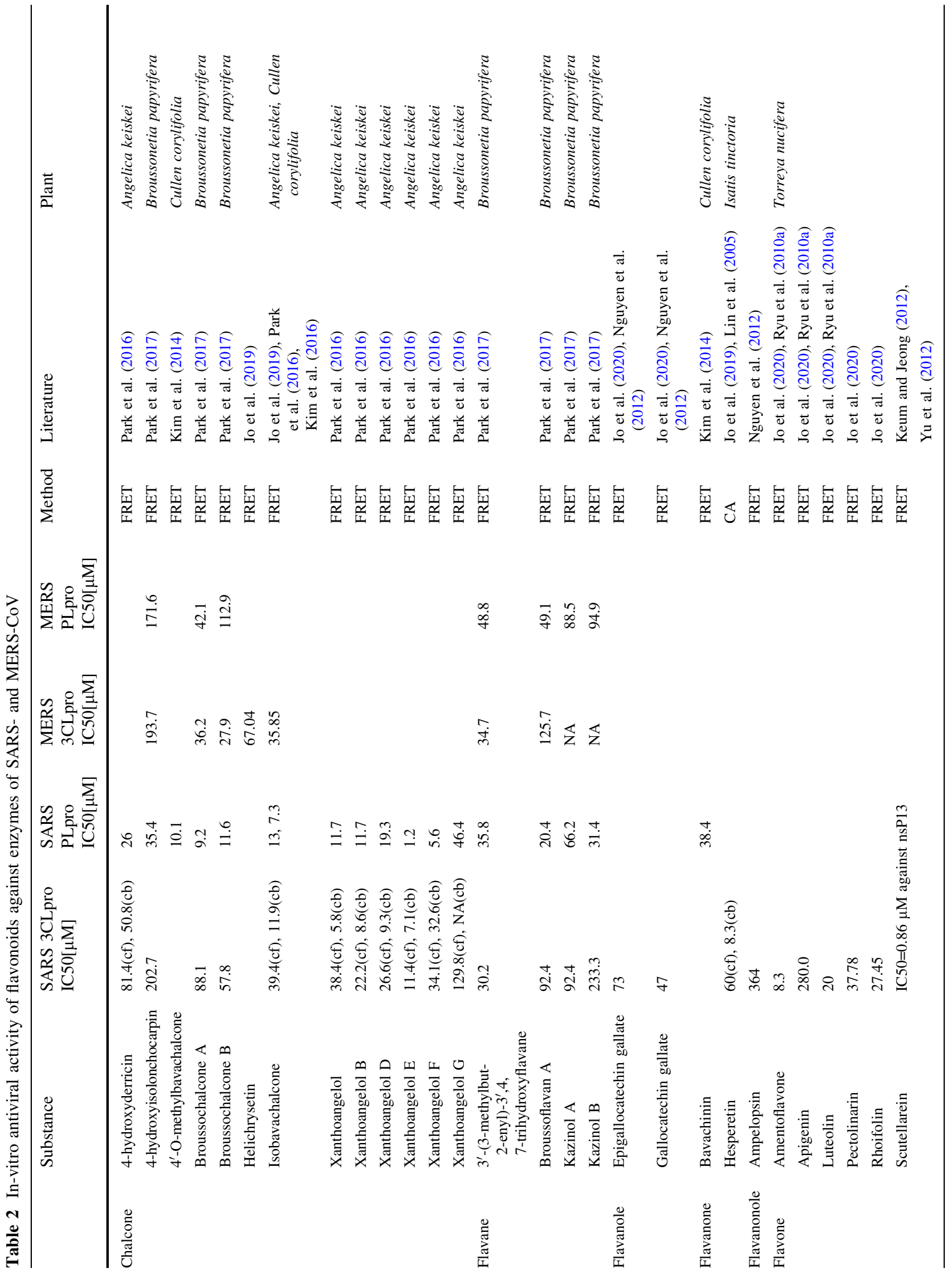




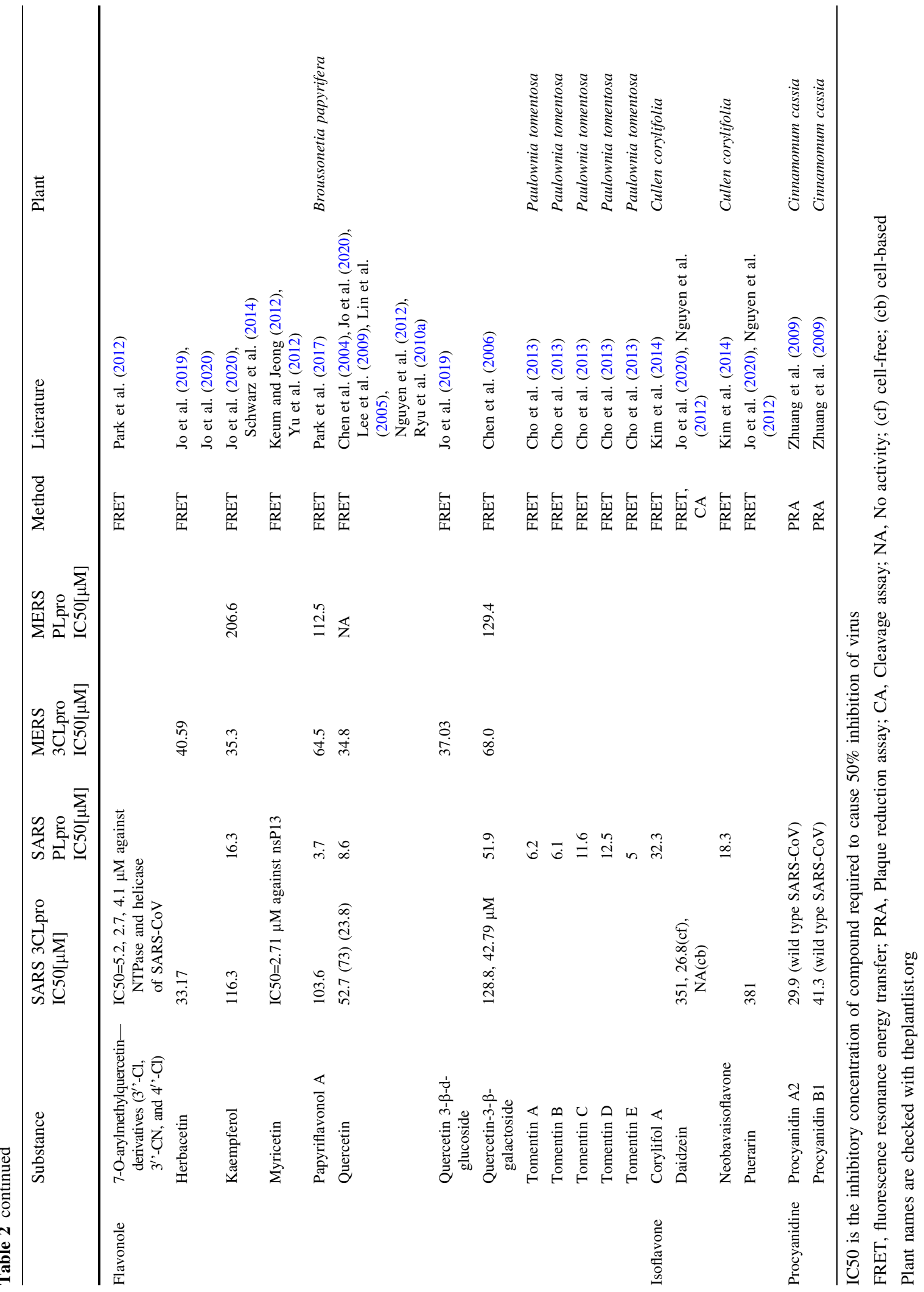


et al. 2017). Structural and functional analyses of SARS-CoV PLpro have revealed that PLpro is homologous to human deubiquitinating enzymes capable of cleaving ubiquitin and ubiquitin-like proteins (Park et al. 2016) and may, therefore, have an important part in the virus life cycle. Hence, antiviral therapeutics targeting PLpro could also prevent the antagonist activities of PLpro on host innate immune response (Ratia et al. 2014).

In FRET-based assays, the proteolytic activity is detected through cleavage of a fluorogenic peptide and measuring the increase in fluorescence intensity by continuously monitoring the reaction (Park et al. 2017). FRET is a non-destructive method, widely exploited to study protein interactions (Margineanu et al. 2016), and is also applied to detect signals in living cells (Huang et al. 2020). While the cell-free FRET assays can provide easy and fast access to proteins including some difficult targets (Sierecki et al. 2013), the cell-based FRET methods enable in situ analysis of a variety of biological targets and proteinprotein interactions in a more natural environment (Silverman et al. 1998). The studies of Park et al. (2017), Lin et al. (2005) and others could prove that flavonoids tested in cell-based assays generated higher activity against $3 \mathrm{CL}$ and PL, than excerting unspecific activity against other enzymes. Furthermore, the unspecific aggregation of proteins often caused by flavonoids could be reduced significantly by the addition of Triton $\mathrm{X}$ without affecting anti-coronaviral activity in these studies.

In a number of studies molecular docking technology was used for screening purposes. Despite the valuable use of this method to rapidly discover novel inhibitors of SARS-CoV-2, there are some disadvantages which include low accuracy and high rate of false-positive results (Wang et al. 2020). However, compounds which are identified through such virtual screening methods can be further examined in highthroughput enzymatic in-vitro assays, followed by more in-depth in vivo investigations, such as studies on efficacy and toxicity.

In general, the combination of docking studies and bioactivity assays can improve screening accuracy by providing supportive data.

\section{Inhibitors of 3CLpro and PLpro}

\section{Chalcones}

Chalcones isolated from Angelica keiskei were shown to inhibit both SARS-CoV proteases PLpro and 3CLpro in enzymatic, FRET-based (Table 2) and molecular docking studies (Park et al. 2016). Inhibition was achieved through a competitive manner against 3CLpro, and a non-competitive mode against PLpro (Park et al. 2016). Xanthoangelol E, an alkylated chalcone substituted with a $-\mathrm{OOH}$ group (Table 1), exerted the most relevant inhibition against 3CLpro $\left(\mathrm{IC}_{50}=11.4\right.$ and $\left.7.1 \mu \mathrm{M}\right)$ and PLpro $\left(\mathrm{IC}_{50-}\right.$ $=1.2 \mu \mathrm{M}$ ) using fluorogenic methods (Park et al. 2016) (Table 2). Analyses of the relationships of the alkylated chalcones (Tables 1 and 2) against 3CLpro showed that xanthoangelol E substituted with 2-perhydroxyl-3-methyl-3-butenyl (PMB) group was more effective than xanthoangelol D with a 2-hydroxy-3methyl-3-butenyl group $\left(\mathrm{IC}_{50}=26.6\right.$ and $\left.9.3 \mu \mathrm{M}\right)$. Similarly, the hydroxyl group of the A-ring caused apparently higher activity than when substituted with a methyl group. Comparing xanthoangelol D and 4-hydroxyderricin, it seemed that the substitution of the A-ring with a 2-hydroxy-3-methyl-3-butenyl group (xanthoangelol D, Table 1) generated higher inhibition than when substituted with the dimethylallyl group (4hydroxyderricin: $\mathrm{IC}_{50}=81.4$ and $50.8 \mu \mathrm{M}$, Table 2) (Park et al. 2016). Based on the results it can be assumed that a perhydroxyl group on the substituted hemiterpene might be crucial for enzyme binding and may affect conformational stabilization of the polyhydroxylated chain through intramolecular hydrogen bonding (Park et al. 2016).

In general, the bioactivity of highly potent compounds against SARS PLpro apparently depended on modifications in their molecular structure, such as prenylation in the $\mathrm{A}$ and $\mathrm{B}$ ring and methylation. For instance, the prenyl moiety of the $3^{\prime}$-prenylated chalcones isobavachalcone and xanthoangelol E led to considerable inhibition against SARS PLpro $\left(\mathrm{IC}_{50-}\right.$ $=7.3$ and $1.2 \mu \mathrm{M}$ ), highlighting the importance of the hydrophobic substituent. Further, it is generally assumed that prenylation of flavonoids may enhance their bioactivity and bioavailability (Grienke et al. 2016; Mukai 2018), presumably by altering lipophilicity and thereby affinity for membrane targets (Shen et al. 2012). Thus, chemical modifications of 
flavonoids, such as the introduction of hydrophobic substituents, may also demonstrate a reasonable strategy to enhance their antiviral activity against SARS-CoV-2.

Some flavonoids isolated from Broussonetia papyrifera have been proposed as useful lead-compounds for the development of anti-CoV agents against SARS and MERS (Park et al. 2017) and therefore, might be also considered to treat SARS-CoV-2. Among them, broussochalcone A, broussochalcone B, and 4-hydroxyisolonchocarpin derived from $B$. papyrifera showed proteolytic activity against both proteases 3CL and PL of SARS- and MERS-CoV (Table 2) through non-competitive inhibition. As Table 2 demonstrates, the compounds showed generally higher inhibitory potential against SARS-CoV PLpro than when tested against the other viral proteases using fluorogenic methods, which is likely related to genomic variations in the single amino acid sequences.

Broussochalcone B was found to be the most effective substrate for inhibiting 3CLpro of MERS$\mathrm{CoV}\left(\mathrm{IC}_{50}=27.9 \mu \mathrm{M}\right)$ in the study of Park et al. (2017). In addition to inhibitory effects on cysteine proteases, the compounds isolated from B. papyrifera caused inhibition against alpha-glucosidase (Park et al. 2017). Inhibition of glycosidases, especially of alpha-glucosidases, affects maturation, transport, secretion, and the functioning of glycoproteins which can enhance cell-cell and/or cell-virus recognition processes (Ryu et al. 2010b). Therefore, it plays a relevant role in the treatment of viral infections, but also in other diseases such as diabetes mellitus type 2, and cancer (Ryu et al. 2010b). In accordance with a previous study (Ryu et al. 2010b), the alpha-glucosidase inhibitory activity of the substrates from $B$. papyrifera depends on the number and positions of prenyl groups present in the molecule (Park et al. 2017).

Kim et al. (2014) could demonstrate that isobavachalcone and 4'-O-methylbavachalcone extracted from the seeds of Cullen corylifolia have great inhibitory potential against SARS-CoV PLpro. Both compounds inhibited PLpro in a dose-dependent manner, with $\mathrm{IC}_{50}$ values of 7.3 and $10.1 \mu \mathrm{M}$ (Table 2) (Kim et al. 2014). Isobavachalcone (2',4,4'-trihydroxy-3'-(3-methyl-2-butenyl) chalcone) also showed inhibitory activity against MERS-CoV 3 CLpro $\left(\mathrm{IC}_{50-}\right.$ $=35.85 \mu \mathrm{M}$, Table 2), when tested within the screening of a flavonoid library using a fluorogenic (FRET-based) method (Jo et al. 2019).

Based on the results summarized in Table 2, the chalcones isobavachalcone, 4'-O-methylbavachalcone, broussochalcone $\mathrm{A}$ and $\mathrm{B}$, including xanthoangelols, can be considered as prominent inhibitory compounds of SARS-CoV PLpro $\left(\mathrm{IC}_{50} \leq 12.5 \mu \mathrm{M}\right.$, Table 2). For comparison, Báez-Santos et al. reviewed numerous inhibitors of SARS-CoV PLpro (BáezSantos et al. 2015) reporting tanshinones and diarylheptanoids as successful inhibitors of SARS-CoV PLpro, with IC50 values of tanshinones ranging from 0.8 to $30.0 \mu \mathrm{M}$ (Báez-Santos et al. 2015). Disulfiram has been suggested to be a putative inhibitor of SARSand MERS-CoV PLpro $\left(\mathrm{IC}_{50}=24.1 \mu \mathrm{M}\right.$ and 14.6 $\mu \mathrm{M})$ (Lin et al. 2018).

Regarding the broad-spectrum activity of chalcones, isobavachalcone presents the major compound in this group - with a good scaffold to bind with proteases of both SARS- and MERS-CoV. Hence, further in-vitro investigations with isobavachalcone on viral proteins of SARS-CoV-2, as well as some pharmacological studies in-vivo regarding toxicity and bioavailability of the compound, might be a valuable approach in the field of research for COVID19. There are a few plant sources of isobavachalcone other than those mentioned in Table 2, as it is abundantly found in species belonging to plant families Fabaceae (e.g., Anthyllis hermanniae, Glycyrrhiza glabra, Glycyrrhiza uralensis, Sophora prostrata) and Moraceae (e.g., Dorstenia poinsettifolia, Dorstenia turbinata, Maclura tinctoria, Treculia acuminata) (Kuete and Sandjo 2012).

Flavanes and flavanols

The flavanes 3'-(3-methylbut-2-enyl)-3', 4,7-trihydroxyflavane, broussoflavan A, kazinol A and kazinol B isolated from Broussonetia papyrifera interfered with viral proteases 3CL and PL of both SARS- and MERS-CoV (Table 2) through non-competitive inhibition (Park et al. 2017). Among all flavanes tested, $3^{\prime}$ (3-methylbut-2-enyl)-3',4,7-trihydroxyflavane, a C5alkyl group (prenyl)-substituted flavan (Table 1), exhibited the most potent inhibition against SARSand MERS-CoV 3CLpro $\left(\mathrm{IC}_{50}=30.2 \mu \mathrm{M}\right.$ and $34.7 \mu \mathrm{M})$. Considering the structure-activity relationships of flavonoids from B. papyrifera (Tables 1 and 2 ), it was observed that molecules having a $\mathrm{C} 4-\mathrm{OH}$ 
group and saturated chromenone with a dihydroxy group at ring $\mathrm{C}$ have stronger inhibitory potential than those with a closed prenyl group such as kazinol B $\left(\mathrm{IC}_{50}=233.3 \mu \mathrm{M}\right.$, Table 2).

Given the results, the flavane 3 '-(3-methylbut-2enyl)-3',4,7-trihydroxyflavane may serve as good template for continuing in-vitro experiments on viral proteases of SARS-CoV-2 due to similar efficacy against proteases of both SARS- and MERS-CoV, and the homology of proteases from the SARS-CoV-2 strain (Fig. 1).

Epigallocatechin gallate (EGCG) and gallocatechin gallate (GCG), two flavanol derivatives, demonstrated inhibitory activity against SARS-CoV 3CLpro, when tested in proteolytic (FRET-based) assays and molecular docking studies of Nguyen et al. (2012). The catechin $\mathrm{GCG}\left(\mathrm{IC}_{50}=47 \mu \mathrm{M}\right)$ inhibited 3CLpro activity (Table 2) by interacting with amino acid residues in the active site pocket of 3CLpro (Nguyen et al. 2012). Analyses of structure-activity relationships of these compounds (Tables 1 and 2) suggest that the galloyl moiety at position 3-OH of EGCG and GCG (Table 1), which is absent in the other catechins, seemed to be relevant for causing 3CLpro inhibition. GCG (2S, 3R type), which is a C-2 epimeric isomer of EGCG (2R, 3R type), generated higher 3CLpro inhibition than that of EGCG $\left(\mathrm{IC}_{50}=73 \mu \mathrm{M}\right)$. In a following docking study, it was shown that the galloyl group of GCG, was essential for hydrogen bond interactions with the amino residues Leu141, Gly143, Ser144, and His163 of the 3CLpro active pocket site (Nguyen et al. 2012). For further studies with these compounds on proteases of SARS-CoV-2 it should be considered that different conformation and structural modifications in the molecules likely increase antiviral activity.

Flavanones and flavanonols

In a study investigating the Chinese medicinal plant Isatis tinctoria root-which was used for the prevention of SARS-CoV during the SARS-outbreaks, and is known for its antiviral properties against influenza, Hepatitis A and Japanese Encephalitis infections (Lin et al. 2005; Wu et al. 1997)—hesperetin was discovered as highly potent inhibitor of SARS-CoV 3CLpro $\left(\mathrm{IC}_{50}=8.3 \mu \mathrm{M}\right)$ when tested in a cell-based cleavage assay (Lin et al. 2005). In comparison with other reported inhibitors of SARS-CoV 3CLpro, such as cinanserin and cinanserin hydrochloride $\left(\mathrm{IC}_{50-}\right.$ $=31 \mu \mathrm{M}$ and $34 \mu \mathrm{M}$, respectively) (Chen et al. 2005a), hesperetin may present a promising lead in the development of SARS-CoV-2 3CL protease inhibitors. However, further screenings on proteolytic activity of hesperetin against PLpro might be also important. Several citrus fruits are the major plant sources of flavanones, including hesperetin-the aglycone of hesperidin.

Bavachinin, a flavanone extracted from the seeds of Cullen corylifolia, was found to have inhibitory potential against SARS-CoV PLpro $\left(\mathrm{IC}_{50}=38.4 \mu \mathrm{M}\right.$, Table 2) (Kim et al. 2014).

Amelopsin, also known as dihydromyricetin, had only weak inhibitory activity against SARS-CoV 3CLpro $\left(\mathrm{IC}_{50}=364 \mu \mathrm{M}\right.$, Table 2$)$ when tested in a proteolytic (FRET-based) assay and molecular docking studies (Nguyen et al. 2012). In the same study, it was observed that the additional $\mathrm{OH}$ group at $5^{\prime}$ position in the $\mathrm{B}$ ring as well as the absence of 2,3double bonds in the C-ring of amelopsin (Table 1) considerably reduced 3CLpro inhibitory activity when compared to other compounds tested, such as quercetin $\left(\mathrm{IC}_{50}=73 \mu \mathrm{M}\right.$, Table 2) (Nguyen et al. 2012).

Flavones and flavonols

Amentoflavone, a biflavone isolated from Torreya nucifera, demonstrated a prominent inhibitor of SARS-CoV 3CLpro $\left(\mathrm{IC}_{50}=8.3 \mu \mathrm{M}\right)$ in a FRETbased assay (Ryu et al. 2010a). In that study, amentoflavone proved to be far more potent than the parent compound apigenin $\left(\mathrm{IC}_{50}=280.8 \mu \mathrm{M}\right)$, and the other flavone luteolin $\left(\mathrm{IC}_{50}=20 \mu \mathrm{M}\right)$, as well as the flavonol quercetin $\left(\mathrm{IC}_{50}=23.8 \mu \mathrm{M}\right)$. By comparing their structures (Table 1), those compounds with a C-3'-substituted hydroxyl group, such as luteolin and quercetin, excerted stronger inhibition than apigenin. Furthermore, biflavone derivatives of amentoflavone with methylation of 7-, 4'-, and $4^{\prime \prime \prime}$-hydroxyl groups, decreased inhibitory activity (Ryu et al. 2010a).

Based on the prominent in vitro inhibition activity of amentoflavone against 3CLpro of SARS-CoV, the compound may serve as a good starting point for further investigations on 3CLpro of SARS-CoV-2due to $79.5 \%$ genome sequence identity (Yang et al. 2020; Zhou et al. 2020), including more than $95 \%$ similarity of 3CLpro amino acid sequences between 
SARS-CoV and SARS-CoV-2 (McKee et al. 2020). However, the biflavonoid should be also tested against other proteases of SARS- and MERS-CoV in order to determine a broad spectrum antiviral efficacy against SARS-CoV-2. There are numerous plant sources from which amentoflavone can be isolated, these include for instance Gingko biloba, Hypericum perforatum, Lobelia chinensis, Polygala sibirica, Ranunculus ternatus, and several plants from Selaginella species, such as Selagenella tamariscina, Selaginella nipponica, and Selaginella pulvinata (Yu et al. 2017).

Two other flavones, pectolinarin and rhoifolin, and the flavonol herbacetin were discovered as inhibitors of SARS-CoV 3CL enzyme when tested in proteolytic assays $\left(\mathrm{IC}_{50} \leq 37.78 \mu \mathrm{M}\right.$, Table 2$)$ and induced-fit docking experiments (Jo et al. 2020). In docking studies, Jo et al. showed that the additional 8-hydroxyl group of herbacetin seems to be crucial for its high binding affinity to the polar S1 site and the hydrophobic S2 site of SARS-CoV 3CLpro (Jo et al. 2020). Furthermore, carbohydrate groups of rhoifolin and pectolinarin were responsible for the high affinity to SARS-CoV 3CLpro (Jo et al. 2020). In another screening using a FRET-based method, herbacetin (3,4',5,7,8-pentahydroxyflavone, Table 1) also caused inhibition against 3CLpro of MERS-CoV at an $\mathrm{IC}_{50}$ value of $40.59 \mu \mathrm{M}$ (Table 2) (Jo et al. 2019). Since herbacetin shows similar inhibitory effects against both 3CL proteases of SARS- and MERS-CoV $\left(\mathrm{IC}_{50}=33.17\right.$ and $\left.40.59 \mu \mathrm{M}\right)$, it may also demonstrate proteolytic activity when tested against SARS-CoV-2 3CL protease. Several 3CLpro inhibitors that have been suggested as candidates for SARS-CoV-2 3CLpro, were found to be effective against 3CLpro of both SARS- and MERS-CoV (He et al. 2020b). Herbacetin can be found, for instance, in Ephedrae herba (Hyuga et al. 2013), Linum usitatissimum (Qiu et al. 1999) and Rhodiola rosea (Péter Zomborszki et al. 2019).

Papyriflavonol A, a double prenylated flavone derivative isolated from Broussonetia papyrifera, presents one of the most significant inhibitors of SARS PLpro at an $\mathrm{IC}_{50}$ value of $3.7 \mu \mathrm{M}$ (Table 2), causing higher activity than other flavonols such as kaempferol $\left(\mathrm{IC}_{50}=16.3 \mu \mathrm{M}\right)$, quercetin $\left(\mathrm{IC}_{50-}\right.$ $=8.6 \mu \mathrm{M})$, and quercetin-beta-galactoside $\left(\mathrm{IC}_{50-}\right.$ $=51.9 \mu \mathrm{M}$ ). Similarly, geranylated flavonols from the fruits of Paulownia tomentosa were found to be the main group of active constituents that successfully interferes with SARS-CoV PLpro (Cho et al. 2013). Among twelve PLpro-inhibitory flavonoids isolated, five new geranylated flavonols named tomentin A-E bearing an unusual 3,4-dihydro-2 $H$-pyran motif with a cyclized geranyl chain (Table 1) caused high inhibition $\left(\mathrm{IC}_{50}\right.$ values $5-12.5 \mu \mathrm{M}$ ) within a FRET-based assay (Table 2). Prenylated and geranylated flavonoids like papyriflavonol $\mathrm{A}$, and tomentins $\left(\mathrm{IC}_{50} \leq 7.3 \mu \mathrm{M}\right.$, Table 2) can be proposed as interesting leads for SARS-CoV-2 PLpro inhibitors due to 83\% homology of PLpro sequences between SARS-CoV and SARSCoV-2 (McKee et al. 2020).

It can be assumed that the hydrophobic substituents of prenylated flavonoids e.g., papyriflavonol A, show higher affinity to SARS-CoV PLpro than to other proteases, which might be due to certain structural differences in the protein sequences. Further, the polarity of the compounds such as an increased number of hydroxyl groups, including the addition of sugar residues in the flavone backbone (Table 1), seems to affect inhibitory potential, as demonstrated by kaempferol $\left(\mathrm{IC}_{50}=16.3 \mu \mathrm{M}\right)$, quercetin $\left(\mathrm{IC}_{50}\right.$ $=8.6 \mu \mathrm{M}), \quad$ and $\quad$ quercetin- $\beta$-galactoside $\left(\mathrm{IC}_{50}=51.9 \mu \mathrm{M}\right)$.

Comparing quercetin with quercetin $\beta$-glycosides - the sugar moieties such as that of quercetin3 - $\beta$-galactoside, and quercetin 3 - $\beta$-d-glucoside did not enhance inhibitory activity against SARS-and MERS$\mathrm{CoV}$ proteases.

In molecular docking studies, quercetin-3- $\beta$-galactoside created hydrophobic interactions with residues Asn142, Glu166, Leu141 and Met165 of SARS 3CLpro (Chen et al. 2006). In particular, the residue Q189 represented a principle factor in the binding between quercetin-3- $\beta$-galactoside and SARS 3CLpro (Chen et al. 2006).

Analyses of structure-activity relationships of quercetin-3- $\beta$-galactoside derivatives suggested that hydroxyl groups on the quercetin moiety are crucial for inhibitory activity, which enable compound-target interaction through hydrogen bonding (Chen et al. 2006).

Quercetin and quercetin 3- $\beta$-glucoside $\left(3,3^{\prime}, 4^{\prime}, 5,7-\right.$ pentahydroxyflavone 3 - $\beta$-glucoside) exerted inhibition when tested against MERS 3CLpro with respective $\mathrm{IC}_{50}$ values of 34.8 and $37.03 \mu \mathrm{M}$ (Table 2) (Jo et al. 2019). In a following docking study, Jo et al. showed that a rhamnose substitution instead of glucose 
(in quercetin 3- $\beta$-glucoside), results in a stronger binding with MERS-CoV 3CLpro (Jo et al. 2019).

In general, quercetin causes a broad range of activities against proteases of SARS- and MERS-CoV (Table 2). Based on that, and the number of sources cited, such as the $\mathrm{IC}_{50}$ values reported in different studies, quercetin is among the most promising agents to treat SARS-CoV-2. Quercetin represents one of the most abundant dietary flavonoids that naturally occurs in a great variety of plant products (medicinal herbs, food, beverages, etc.) (Anand David et al. 2016; Pandey and Rizvi 2009). A few of these rich sources from which quercetin can be isolated include: Allium cepa, Allium fistulosum, Asparagus officinalis, Camellia sinensis, Capparis spinosa, Coriandrum sativum, Ginkgo biloba, Hypericum perforatum, Moringa oleifeira, Punica granatum (Howell and D'Souza 2013), Sambucus canadensis (Anand David et al. 2016; Li et al. 2016).

Isoflavones

The isoflavones, daidzein $\left(\mathrm{IC}_{50}=351 \mu \mathrm{M}\right)$ and puerarin $\left(\mathrm{IC}_{50}=381 \mu \mathrm{M}\right)$ lacking the B-ring in their 3-phenyl-4H-1-benzopyran-4-one backbone (Table 1), showed only weak inhibition of SARS-CoV 3CLpro, as demonstrated in Table 2. Neobavaisoflavonestructurally related to daidzein-prenylated at $\mathrm{C}^{\prime}$, and corylifol A extracted from the seeds of Cullen corylifolia, were found to have good inhibitory potential against SARS-CoV PLpro $\left(\mathrm{IC}_{50}=18.3\right.$ and $32.3 \mu \mathrm{M}$ ) (Kim et al. 2014). As mentioned before, flavonoids with lipophilic substituents like prenyl or geranyl side chains in the A or B ring (Table 1) appear to be very good scaffolds to bind with PL proteases, and may therefore be considered as templates for the development of SARS-CoV-2 PLpro inhibitors. Isoflavonoids are predominantly found in legumes; prenylated derivatives can be mainly isolated from the plant familiy Fabaceae (Šmejkal 2014).

\section{Inhibition of RNA-dependent RNA polymerase and Helicase}

Flavones and flavonols

A screening of 64 natural compounds against SARS$\mathrm{CoV}$ helicase led to the identification of scutellarein and myricetin-two strong inhibitors of SARS nsP13 (Table 2) using an ATP hydrolysis assay (Keum and Jeong 2012; Yu et al. 2012). The non-structural proteins (nsPs), which are processed by the viral proteases PL (residing in nsp3) and 3CL (residing in nsp5), comprise the RNA-dependent RNA polymerase and the NTPase/helicase-two essential determinants for virus replication (Adedeji et al. 2012). The SARS helicase nsP13 protein has been shown to have doublestrand (ds) RNA and (ds) DNA unwinding activity and can translocate along the nucleic acids by hydrolyzing ATP (Lee et al. 2010). Both compounds, the flavone scutellarein and the flavonol myricetin, successfully impaired ATPase activity of nsP13 with respective $\mathrm{IC}_{50}$ values of $0.86 \mu \mathrm{M}$ and $2.71 \mu \mathrm{M}$ (Table 2). This effect was mediated through inhibition of ATPase activity, but did not affect dsDNA-unwinding activity of SARS helicase, as it was demonstrated in a fluorometric, FRET-based, dsDNA unwinding assay of Yu et al. (2012).

Myricetin naturally occurs in high concentrations in different fruits (e.g., cranberry) (Singh et al. 2009), and vegetables such as spinach, cauliflower etc. (Sultana and Anwar 2008). Scutellarein can be found in members of the genus Scutellaria such as Scutellaria baicalensis - an important traditional Chinese plant used against diverse infections including inflammatory or respiratory diseases (Zhao et al. 2016).

Another study evaluating 24 derivatives of 7-Oaryl-methylquercetin for their antiviral activity against SARS-CoV, three derivatives with $3^{\prime \prime}-\mathrm{Cl}, 3^{\prime \prime}-\mathrm{CN}$, and $4^{\prime \prime}$ - $\mathrm{Cl}$ aromatic substituents showed selective inhibition of SARS-CoV NTPase/helicase activity by performing a FRET-based dsDNA unwinding assay (Park et al. 2012). The introduction of an arylmethyl substituent, such as $3-\mathrm{ClPhCH} 2,3-\mathrm{CNPhCH} 2$ and 4-ClPhCH2, at the position 7-OH of quercetin (Table 1), led to stronger inhibition against SARS$\mathrm{CoV}$ helicase $\left(\mathrm{IC}_{50}\right.$ values of $5.2,2.7,4.1 \mu \mathrm{M}$, respectively) than that of quercetin $\left(\mathrm{IC}_{50}=8.1 \mu \mathrm{M}\right)$ (Park et al. 2012).

\section{Inhibition of S protein}

Flavones and flavonols

The spike (S) protein of CoVs is responsible for viral entry into target cells through binding to the 
angiotensin-converting enzyme 2 (ACE2) receptor on host cell membranes (Zhou et al. 2020), and thus presents another important target in the anti-SARSCoV-2 drug development. Besides the inhibitory potential of luteolin against SARS 3CL protease $\left(\mathrm{IC}_{50}=20 \mu \mathrm{M}\right.$, Table 2), the flavone was found to successfully impede the entry process of SARS-CoV into host cells by interfering with the $S$ protein of SARS-CoV $\left(\mathrm{EC}_{50}\right.$ value $\left.=10.6 \mu \mathrm{M}\right)$ in a two-step screening method combining frontal affinity chromatography-mass spectrometry (FAC/MS) and pseudotyped virus-infection assay (Yi et al. 2004). Likewise, quercetin was found to block host cell entry $\left(\mathrm{EC}_{50}=83.4 \mu \mathrm{M}\right)$ when tested in HIV-luciferase/ SARS pseudotyped virus assay (Yi et al. 2004). The use of pseudotyped viruses is reported to be a powerful, rapid, and highly sensitive method for studying the entry process of viruses to host cells (Yi et al. 2004).

Since SARS-CoV and SARS-CoV-2 share high sequence similarity of the $\mathrm{S}$ proteins, these compounds may be also expected to impede the entry of SARSCoV-2 into host cells. Furthermore, it is proven that the S protein of SARS-CoV-2 binds with 10-20-fold higher affinity to ACE2 than that of SARS-CoV (McKee et al. 2020). Thus, inhibition of ACE2 via a competing substance, seems to be a reasonable approach for preventing SARS-CoV-2 infections. Quercetin had potent inhibitory effects on ACE in vitro, and in vivo when tested in rat models (Actis-Goretta et al. 2006; Al Shukor et al. 2013; Guerrero et al. 2012; Nileeka Balasuriya and Vasantha Rupasinghe 2011). However, ACE inhibitors-which are standard therapeutics for the treatment of high blood pressure (Actis-Goretta et al. 2006), and may have a vital role in viral infections and pneumonia (Henry et al. 2018) - have not yet been shown to inhibit ACE2.

\section{Non-specific inhibition of SARS-CoV}

Flavones and flavonols

Baicalin, a flavone glycoside and major constituent of Scutellaria baicalensis, was found to have antiviral in vitro activity against SARS-CoV (12.5 to $25 \mu \mathrm{g} / \mathrm{ml}$ after $48 \mathrm{~h}$; and 25 to $50 \mu \mathrm{g} / \mathrm{ml}$ after $72 \mathrm{~h}$ ) when screened against 10 clinical isolates of SARS-CoV with foetal rhesus kidney-4 cells tested in a plaque reduction assay (Chen et al. 2004). For comparison, lopinavir-a protease inhibitor used against HIV infections, and which is currently in clinical trials for anti-SARS-CoV-2 infections-showed antiviral efficacy against SARS-CoV infected fetal rhesus kidney4-cells at a concentration of $4 \mu \mathrm{g} / \mathrm{mL}$, using the same assay (Chu et al. 2004). Baicalin is also a known inhibitor of HIV-1 reverse transcriptase ( $\mathrm{Li}$ et al. 2000), and was shown to possess inhibitory potential against influenza in vitro and in vivo by acting as immune modulator promoting IFN- $\gamma$ production in mice and human CD4 + and CD8 + T cells (Chu et al. 2015; Ding et al. 2014).

In general, some HIV protease inhibitors e.g., lopinavir, ritonavir or nelfinavir could interfere with SARS-CoV replication in-vitro, and had binding affinity to SARS-CoV 3CLpro (Zhang et al. 2004). Based on available evidence, it is controversial whether antiretroviral drugs can be suggested for the treatment of coronavirus diseases such as SARS-CoV2. However, flavonoids which were found to have antiHIV activity may be still worth investigating for their anti-SARS-CoV-2 potential. For example, baicalein, another major component from Scutellaria baicalensis, has been described for its anti-HIV properties such as its binding to HIV-1 integrase (Hu et al. 2010; Zhao et al. 2016), and thus might be proposed as interesting lead compound for SARS-CoV-2 drug discovery.

In addition to the inhibitory potency of kaempferol against SARS-CoV proteases (Table 2), the flavonol was able to block the $3 \mathrm{a}$ ion channel of SARS-CoV, a protein encoded by the open-reading-frame (ORF) 3a, which is involved in the virus release mechanism (Schwarz et al. 2011). Schwarz et al. demonstrated that glycosides of kaempferol are stronger inhibitors, highlighting the importance of sugar residues (Schwarz et al. 2014). The kaempferol glycoside juglanin having an arabinose residue, was shown to be the most prominent substrate $\left(\mathrm{IC}_{50}\right.$ value $\left.=2.3 \mu \mathrm{M}\right)($ Schwarz et al. 2014).

Procyanidins

Procyanidins such as procyanidin A2, and procyanidin B1 isolated from Cinnamomi Cortex had inhibitory potential against wild-type SARS-CoV using a plaque reduction assay $\left(\mathrm{IC}_{50}=29.9\right.$ and $41.3 \mu \mathrm{M}$, Table 2 ). However, it was reported that the interplay of all 
procyanidins in the extracts from Cinnamomi Cortex appeared to be crucial for causing strong activity against wild-type SARS-CoV (Zhuang et al. 2009). Plaque reduction assays do not indicate any specific inhibition mechanism of the compounds, but provide a fast and high throughput pre-screening method.

\section{Most promising flavonoids with anti-SARS-CoV-2 potential}

Analyses of 17 studies based on flavonoids as anti$\mathrm{CoV}$ agents revealed 47 compounds (Table 2) as possible agents against SARS-CoV-2. Among them, 16 compounds were investigated in at least two independent studies. 4 of these compounds, quercetin, herbacetin, isobavachalcone, and kaempferol, show activity against at least two viral targets. According to the high $\mathrm{IC}_{50}$ values of kaempferol $(116.3 \mu \mathrm{M}$ against SARS-CoV 3CLpro, and $206.6 \mu \mathrm{M}$ against MERSCoV PLpro), we do not consider this compound a promising candidate to treat SARS-CoV-2. Therefore, the flavonols, herbacetin and quercetin, along with isobavachalcone (Fig. 2) were identified to be the most attractive antiviral leads against SARS-CoV2.-Due to their $\mathrm{IC}_{50}$ values and broad-spectrum activity against proteases of SARS- and MERS-CoV described in different studies (Table 2), as well as their availability from different plant sources. Given the similarity of the genomic sequences encoding the 3CLpro and PLpro catalytic sites of SARS-CoV-2, SARS-CoV, and MERS-CoV (Fig. 1), 3CLpro and PLpro inhibitors of SARS- and MERS-CoV are expected to be valuable leads for treating SARSCoV-2 infections and COVID-19. For instance, remdesivir - one of the most important antiviral drugs which has been suggested for therapeutic use against SARS-CoV-2 - showed broad-efficacy against both SARS- and MERS-CoV (Sheahan et al. 2017, 2020).

Based on the high $\mathrm{CC}_{50}$ values of the active flavonoids, such as that of herbacetin $\mathrm{CC}_{50}=$ 293.7 $\mu \mathrm{M}$ (Jeong et al. 2009) and quercetin $\mathrm{CC}_{50}=$ $385.5 \mu \mathrm{M}$ (Chiow et al. 2016), they can be used in higher concentrations in therapeutic treatments without causing any substantial cytotoxic effects. Prenylated flavonoids like isobavachalcone, are reported be relatively non-toxic to non-cancer cells (Šmejkal 2014), and can be found in significant amounts in the plant families Moraceae, and Fabaceae (Kuete and Sandjo 2012).

As quercetin, herbacetin and isobavachalcone are readily available in high amounts from several plant sources, this might be also beneficial for future investigations on SARS-CoV-2, and the development of anti-CoV therapeutics.

Although the daily intake of plant food may appear to be a readily accessible source of active flavonoids, there is no scientific evidence that a high consumption of flavonoid-rich food and/or supplements, like that of quercetin, provides significant protection against viral diseases in humans e.g., against SARS-CoV-2. Due to low bioavailability, fast metabolism and elimination of flavonoids, the biological functions of these dietary polyphenols in-vivo are likely to be compromised. On the other hand, there are some external, non-host related, factors limiting the bioavailability of dietary flavonoids which include: environmental factors (i.e., storage, sun exposure), food processing factors (i.e., cooking), the interaction with other polyphenols present in plant-based food (i.e., antagonistic actions), the chemical structure (i.e., polymer or in glycosylated structure) and the concentration of the dietary compounds (D'Archivio et al. 2010).

Besides strong inhibitory effects of flavonols and chalcones on SARS- and MERS-CoV, these flavonoids also have some anti-inflammatory (Choy et al. 2019; Ur Rashid et al. 2019) and immune-modulating properties (Hosseinzade et al. 2019), which can be highly beneficial in the host immune response to viral infections. As an example, quercetin which is welldocumented for its wide spectrum of antiviral functions (Zakaryan et al. 2017), had antiviral effects against rhinovirus (RV) infections in-vitro and in-vivo using RV-infected mice, by reducing the expression of pro-inflammatory cytokines and chemokines (Ganesan et al. 2012). Hence, due to different important functions they can be valuable for either preventing and treating viral infections, as well as for alleviating symptoms (e.g., fever, cough, etc.) that may occur during the course of viral infections like that of SARSCoV-2.

In general, quercetin can be considered a highly potent candidate for treating SARS-CoV-2, as it has affinity to a variety of anti-CoV drug targets. The flavonol interfered with the viral replication of SARSCoV by blocking the enzymatic activities of 3CLpro, PLpro (Table 2) and helicase $\left(\mathrm{IC}_{50}=8.1 \mu \mathrm{M}\right)($ Lee 
et al. 2009), but also impaired SARS PLpro cleavage activity of ubiquitin and interferon-stimulated gene (ISG) $15\left(\mathrm{IC}_{50}=20.7\right.$ and $34.4 \mu \mathrm{M}$, respectively) (Park et al. 2017), which can be important for both the viral replication and the host immune response to viruses (Cho et al. 2013). Moreover, quercetin interacted with SARS-CoV at host cell entry level by binding to the $\mathrm{S}$ glycoprotein $\left(\mathrm{EC}_{50}=83.4 \mu \mathrm{M}\right)$ that docks to the host receptor ACE2 (Zhou et al. 2020). Further, quercetin demonstrated proteolytic activity against MERS-CoV 3CLpro $\quad\left(\mathrm{IC}_{50}=34.8 \mu \mathrm{M}\right.$, Table 2).

Future perspective of flavonoids in therapeutic use

Although quercetin, herbacetin and isobavachalcone represent effective compounds against SARS and/or MERS-CoV in vitro, it does not directly indicate their in vivo efficiency or clinical use as anti-SARS-CoV-2 therapeutics. Further experimental in-vivo studies are suggested to evaluate their possible preclinical and clinical efficacy for the prevention of SARS-CoV-2 infections and the treatment of COVID-19.

For that purpose, there are a few issues that need to be addressed.

Since polyphenolic compounds are known for their aggregating tendency, doubts have been raised about the reliability of in vitro bioassay data of flavonoids, as false-positive results may occur through non-specific binding of phenolic compounds to proteins (Pohjala and Tammela 2012). The formation of aggregates can cause a non-specific inhibition by sequestering enzyme molecules, absorbing or adsorbing them within their structure and thus causing denaturation (Coan et al. 2009; Pohjala and Tammela 2012). Quercetin, which is one of the best studied flavonoid, showing virucidal activity against various enveloped viruses (e.g., influenza (Wu et al. 2015), parainfluenza type 3, herpes simplex (Chen et al. 2006)), was among the flavonoids that form large aggregates and thus may operate as a promiscuous inhibitor affecting various unrelated targets (Pohjala and Tammela 2012). However, it has been reported that the addition of Triton $\mathrm{X}-100$, a solubilizing agent, to proteolytic assays, can help to reduce aggregate formation and complexation, such as that of flavonoids (Jo et al. 2020; Pohjala and Tammela 2012). Besides the limitations of the bioassays, there is another aspect-the in-vitro molecular assays and cell-based assays do not provide any information about the bioavailability of the compounds. However, this aspect is not within the scope of the review, but for developing flavonoids further, this aspect should be considered. Therefore, it is important to address the bioavailability of flavonoids as one of the critical limiting factors in their therapeutic use. Different strategies to enhance the stability, solubility and systemic distribution of flavonoids have been reported, which can be employed. These include nanotechnology, co-crystallization, absorption enhancers and structural transformations (e.g. prodrugs, glycosylation) (Ajazuddin and Saraf 2010; Zhao et al. 2019).

The use of the flavonoids quercetin, herbacetin, and isobavachalcone in adjuvant therapy with other proposed antiviral drugs may present another interesting approach to combat SARS-CoV-2 infections. Combination therapy often leads to better outcomes in antiviral treatments. For instance, it was found that synergistic effects between quercetin and the antiviral agent aciclovir resulted in enhanced antiviral activity against pseudorabies herpesvirus infection in-vitro (Ahmad et al. 2015). Similarly, $\alpha$-glucoside inhibitors applied together with ribavirin, a standard antiviral drug, could improve antiviral efficacy against dengue infection in vitro and in vivo (Chang et al. 2011).

Furthermore, it should be also evaluated whether the pure flavonoid itself like quercetin, herbacetin, and isobavachalcone, or adminstered in combination with other flavonoids and/or natural compounds can achieve optimal health benefits.

The increasing development of drug-resistance in antiviral treatment might be another critical matter for the therapeutic use of flavonoids.

\section{Conclusions}

Literature search in PubMed, has led to the identification of numerous flavonoids exerting antiviral in vitro activity against SARS and/or MERS coronavirus, primarily by inhibiting the enzymatic activity of $3 \mathrm{CL}$ and PL. Flavonols and chalcones were found to be the main groups of flavonoids containing the highest number of effective compounds against 3CL and PL proteases. In particular, herbacetin, quercetin and isobavachalcone (Fig. 3) were identified as promising antiviral leads against SARS- and MERS$\mathrm{CoV}$ based on their broad-spectrum activity against 
<smiles>O=c1c(O)c(-c2ccc(O)c(O)c2)oc2cc(O)cc(O)c12</smiles>

Quercetin<smiles>O=c1c(O)c(-c2ccc(O)cc2)oc2c(O)c(O)cc(O)c12</smiles>

Herbacetin<smiles>CC(C)=CCc1c(O)ccc(C/C=C/c2ccc(O)cc2)c1O</smiles>

Isobavachalcone

Fig. 3 Chemical structures of the most promising flavonoids

the viral proteases 3CL and PL of both CoVs, the number of relevant literature data, and the availability of the compounds from different plant sources. Considering the fact that quercetin could interfere with SARS-CoV at different levels, such as at the viral entry and replication process, as well as with $3 \mathrm{CL}$ protease of MERS-CoV, we specifically propose this compound to be a highly valuable anti-SARS-CoV-2 candidate. Quercetin may prevent host cell entry of SARS-CoV through binding to the $S$ protein and inhibiting ACE. Further, the flavonol can impair the viral replication of SARS- and MERS-CoV by blocking the enzymatic activites of 3CL and PL including SARS-helicase, and can inhibit the deubiquitination and deISGylation process of SARS PLpro, which might be also an issue in the host immune response. Other potent substrates able to interact with the enzymatic activity of SARS- and MERS-CoV proteases, were found to be prenylated flavonoids (e.g., isobavachalcone). However, despite some promising inhibitory activities of flavonoids against SARS- and MERS-CoV in vitro, none of these compounds have been tested in vivo using animal and/or human cell models. Therefore, more detailed investigations on pharmacological mechanisms, long-term toxicology, bioavailability, as well as some additional studies on possible herb-drug interactions are required. In fact, natural compounds like flavonoids, continue to be a wealthy source for the discovery of novel antiviral agents. It was reported that natural substrates from Traditional Chinese Medicine (TCM) seemed to have a positive impact on the recovery process of patients suffering from SARS-CoV diseases, by mitigating possible side effects of conventional therapeutics (Yang et al. 2020). Since flavonoids are well-documented for their broad spectrum of health-beneficial properties, especially anti-inflammatory and antioxidative effects, they could be of great value for strengthening the host immune response to viral diseases, and alleviating infection-related symptoms, such as down-regulating overwhelming inflammatory responses (e.g. cytokine production). For instance, besides the antiviral effects of quercetin, the flavonol was found to prevent tissue damage by scavenging free radicals, and could reduce the release of inflammatory cytokines such as interleukine IL-8 (Kinker 2014).

Due to high similarities of SARS-CoV, SARSCoV-2, and MERS-CoV-sharing several homologous viral proteases, the proposed flavonols herbacetin and quercetin, as well as isobavachalcone may demonstrate attractive antiviral substrates against SARS-CoV-2 and/or other coronaviruses. However, further research and more detailed pharmacological investigations in-vivo, particularly on the bioavailability of these compounds, appear to be a promising approach for the discovery of novel herbal substrates used as adjunctive therapeutics in the treatment of coronavirus diseases, such as COVID-19. Furthermore, greater attention should be paid to combinatory effects of flavonoids, especially when used together with other standard antiviral drugs.

Acknowledgements Open access funding provided by University of Graz is greatly acknowledged. 
Author contributions Julia Solnier and Johannes-Paul Fladerer contributed equally to this work.

Funding Open access funding provided by University of Graz.

\section{Compliance with ethical standards}

Conflict of interest The authors declare that they have no conflict of interest.

Open Access This article is licensed under a Creative Commons Attribution 4.0 International License, which permits use, sharing, adaptation, distribution and reproduction in any medium or format, as long as you give appropriate credit to the original author(s) and the source, provide a link to the Creative Commons licence, and indicate if changes were made. The images or other third party material in this article are included in the article's Creative Commons licence, unless indicated otherwise in a credit line to the material. If material is not included in the article's Creative Commons licence and your intended use is not permitted by statutory regulation or exceeds the permitted use, you will need to obtain permission directly from the copyright holder. To view a copy of this licence, visit http://creativecommons.org/licenses/by/4.0/.

\section{References}

Abreu AC, Coqueiro A, Sultan AR, Lemmens N, Kim HK, Verpoorte R, van Wamel WJB, Simões M, Choi YH (2017) Looking to nature for a new concept in antimicrobial treatments: isoflavonoids from Cytisus striatus as antibiotic adjuvants against MRSA. Sci Rep 7:3777. https://doi.org/ 10.1038/s41598-017-03716-7

Actis-Goretta L, Ottaviani JI, Fraga CG (2006) Inhibition of angiotensin converting enzyme activity by flavanol-rich foods. J Agric Food Chem 54:229-234. https://doi.org/10. 1021/jf052263o

Adedeji AO, Marchand B, Te Velthuis AJW, Snijder EJ, Weiss S, Eoff RL, Singh K, Sarafianos SG (2012) Mechanism of nucleic acid unwinding by SARS-CoV helicase. PLoS ONE 7:e36521. https://doi.org/10.1371/journal.pone.0036 521

Ahmad A, Kaleem M, Ahmed Z, Shafiq H (2015) Therapeutic potential of flavonoids and their mechanism of action against microbial and viral infections-a review. Food Res Int 77:221-235. https://doi.org/10.1016/j.foodres.2015.06. 021

Ajazuddin SS (2010) Applications of novel drug delivery system for herbal formulations. Fitoterapia 81:680-689. https://doi.org/10.1016/j.fitote.2010.05.001

Al Shukor N, van Camp J, Gonzales GB, Staljanssens D, Struijs K, Zotti MJ, Raes K, Smagghe G (2013) Angiotensinconverting enzyme inhibitory effects by plant phenolic compounds: a study of structure activity relationships. J Agric Food Chem 61:11832-11839. https://doi.org/10. 1021/jf404641v
Anand K, Ziebuhr J, Wadhwani P, Mesters JR, Hilgenfeld R (2003) Coronavirus main proteinase (3CLpro) structure: basis for design of anti-SARS drugs. Science 300:1763-1767. https://doi.org/10.1126/science.1085658

Anand David AV, Arulmoli R, Parasuraman S (2016) Overviews of biological importance of quercetin: a bioactive flavonoid. Pharmacogn Rev 10:84-89. https://doi.org/10. 4103/0973-7847.194044

Báez-Santos YM, St John SE, Mesecar AD (2015) The SARScoronavirus papain-like protease: structure, function and inhibition by designed antiviral compounds. Antiviral Res 115:21-38. https://doi.org/10.1016/j.antiviral.2014.12.015

Cascella M, Rajnik M, Cuomo A, Dulebohn SC, Di Napoli R (2020) StatPearls: features, evaluation and treatment coronavirus (COVID-19)

Catarino MD, Talhi O, Rabahi A, Silva AMS, Cardoso SM (2016) The antiinflammatory potential of flavonoids. Stud Nat Prod Chem 48:65-99. https://doi.org/10.1016/B978-0444-63602-7.00003-5

Centers for Disease Control and Prevention (2020) Human Coronavirus Types: common human coronaviruses. https:// www.cdc.gov/coronavirus/types.html. Accessed 25 March 2020

Chang J, Schul W, Butters TD, Yip A, Liu B, Goh A, Lakshminarayana SB, Alonzi D, Reinkensmeier G, Pan X, Qu X, Weidner JM, Wang L, Yu W, Borune N, Kinch MA, Rayahin JE, Moriarty R, Xu X, Shi P-Y, Guo J-T, Block TM (2011) Combination of $\alpha$-glucosidase inhibitor and ribavirin for the treatment of dengue virus infection in vitro and in vivo. Antiviral Res 89:26-34. https://doi.org/10. 1016/j.antiviral.2010.11.002

Chen F, Chan KH, Jiang Y, Kao RYT, Lu HT, Fan KW, Cheng VCC, Tsui WHW, Hung IFN, Lee TSW, Guan Y, Peiris JSM, Yuen KY (2004) In vitro susceptibility of 10 clinical isolates of SARS coronavirus to selected antiviral compounds. J Clin Virol 31:69-75. https://doi.org/10.1016/j. jcv.2004.03.003

Chen L, Gui C, Luo X, Yang Q, Günther S, Scandella E, Drosten C, Bai D, He X, Ludewig B, Chen J, Luo H, Yang Y, Yang Y, Zou J, Thiel V, Chen K, Shen J, Shen X, Jiang H (2005a) Cinanserin is an inhibitor of the $3 \mathrm{C}$-like proteinase of severe acute respiratory syndrome coronavirus and strongly reduces virus replication in vitro. J Virol 79:7095-7103. https://doi.org/10.1128/JVI.79.11.70957103.2005

Chen C-N, Lin CPC, Huang K-K, Chen W-C, Hsieh H-P, Liang P-H, Hsu JT-A (2005b) Inhibition of SARS-CoV 3C-like protease activity by theaflavin-3,3'-digallate (TF3). Evid Based Complement Alternat Med 2:209-215. https://doi. org/10.1093/ecam/neh081

Chen L, Li J, Luo C, Liu H, Xu W, Chen G, Liew OW, Zhu W, Puah CM, Shen X, Jiang H (2006) Binding interaction of quercetin-3-beta-galactoside and its synthetic derivatives with SARS-CoV 3CL(pro): structure-activity relationship studies reveal salient pharmacophore features. Bioorg Med Chem 14:8295-8306. https://doi.org/10.1016/j.bmc.2006. 09.014

Chen I-Y, Moriyama M, Chang M-F, Ichinohe T (2019) Severe acute respiratory syndrome coronavirus viroporin $3 \mathrm{a}$ activates the NLRP3 inflammasome. Front Microbiol 10:50. https://doi.org/10.3389/fmicb.2019.00050 
Chiow KH, Phoon MC, Putti T, Tan BKH, Chow VT (2016) Evaluation of antiviral activities of Houttuynia cordata Thunb. extract, quercetin, quercetrin and cinanserin on murine coronavirus and dengue virus infection. Asian Pac J Trop Med 9:1-7. https://doi.org/10.1016/j.apjtm.2015.12. 002

Cho JK, Curtis-Long MJ, Lee KH, Kim DW, Ryu HW, Yuk HJ, Park KH (2013) Geranylated flavonoids displaying SARS$\mathrm{CoV}$ papain-like protease inhibition from the fruits of Paulownia tomentosa. Bioorg Med Chem 21:3051-3057. https://doi.org/10.1016/j.bmc.2013.03.027

Choy KW, Murugan D, Leong X-F, Abas R, Alias A, Mustafa MR (2019) Flavonoids as natural anti-inflammatory agents targeting nuclear factor-kappa $\mathrm{B}(\mathrm{NF} \mathrm{B})$ signaling in cardiovascular diseases: a mini review. Front Pharmacol 10:1295. https://doi.org/10.3389/fphar.2019.01295

Chu M, Xu L, Zhang M-B, Chu Z-Y, Wang Y-D (2015) Role of baicalin in anti-influenza virus $A$ as a potent inducer of IFN-gamma. Biomed Res Int 2015:263630. https://doi.org/ $10.1155 / 2015 / 263630$

Chu CM, Cheng VCC, Hung IFN, Wong MML, Chan KH, Chan KS, Kao RYT, Poon LLM, Wong CLP, Guan Y, Peiris JSM, Yuen KY (2004) Role of lopinavir/ritonavir in the treatment of SARS: initial virological and clinical findings

Chuck C-P, Chow H-F, Wan DC-C, Wong K-B (2011) Profiling of substrate specificities of 3C-like proteases from group 1, 2a, 2b, and 3 coronaviruses. PLoS ONE 6:e27228. https:// doi.org/10.1371/journal.pone.0027228

Coan KED, Maltby DA, Burlingame AL, Shoichet BK (2009) Promiscuous aggregate-based inhibitors promote enzyme unfolding. J Med Chem 52:2067-2075. https://doi.org/10. 1021/jm801605r

D'Amelia V, Aversano R, Chiaiese P, Carputo D (2018) The antioxidant properties of plant flavonoids: their exploitation by molecular plant breeding. Phytochem Rev 17:611-625. https://doi.org/10.1007/s11101-018-9568-y

D’Archivio M, Filesi C, Varì R, Scazzocchio B, Masella R (2010) Bioavailability of the polyphenols: status and controversies. Int J Mol Sci 11:1321-1342. https://doi.org/10. 3390/ijms11041321

Ding Y, Dou J, Teng Z, Yu J, Wang T, Lu N, Wang H, Zhou C (2014) Antiviral activity of baicalin against influenza A (H1N1/H3N2) virus in cell culture and in mice and its inhibition of neuraminidase. Arch Virol 159:3269-3278. https://doi.org/10.1007/s00705-014-2192-2

Dong W, Wei X, Zhang F, Hao J, Huang F, Zhang C, Liang W (2014) A dual character of flavonoids in influenza A virus replication and spread through modulating cell-autonomous immunity by MAPK signaling pathways. Sci Rep 4:7237. https://doi.org/10.1038/srep07237

Fehr AR, Perlman S (2015) Coronaviruses: an overview of their replication and pathogenesis. Methods Mol Biol 1282:1-23. https://doi.org/10.1007/978-1-4939-2438-7_1

Ganesan S, Faris AN, Comstock AT, Wang Q, Nanua S, Hershenson MB, Sajjan US (2012) Quercetin inhibits rhinovirus replication in vitro and in vivo. Antiviral Res 94:258-271. https://doi.org/10.1016/j.antiviral.2012. 03.005

Goetz DH, Choe Y, Hansell E, Chen YT, McDowell M, Jonsson CB, Roush WR, McKerrow J, Craik CS (2007) Substrate specificity profiling and identification of a new class of inhibitor for the major protease of the SARS coronavirus. Biochemistry 46:8744-8752. https://doi.org/10.1021/ bi0621415

Gordon CJ, Tchesnokov EP, Feng JY, Porter DP, Gotte M (2020) The antiviral compound remdesivir potently inhibits RNA-dependent RNA polymerase from Middle East respiratory syndrome coronavirus. J Biol Chem. https:// doi.org/10.1074/jbc.AC120.013056

Grienke U, Richter M, Walther E, Hoffmann A, Kirchmair J, Makarov V, Nietzsche S, Schmidtke M, Rollinger JM (2016) Discovery of prenylated flavonoids with dual activity against influenza virus and Streptococcus pneumoniae. Sci Rep 6:27156. https://doi.org/10.1038/ srep27156

Guerrero L, Castillo J, Quiñones M, Garcia-Vallvé S, Arola L, Pujadas G, Muguerza B (2012) Inhibition of angiotensinconverting enzyme activity by flavonoids: structure-activity relationship studies. PLoS ONE 7:e49493. https://doi. org/10.1371/journal.pone.0049493

Gurwitz D (2020) Angiotensin receptor blockers as tentative SARS-CoV-2 therapeutics. Drug Dev Res. https://doi.org/ $10.1002 / \mathrm{ddr} .21656$

He F, Deng Y, Li W (2020a) Coronavirus disease 2019 (COVID-19): what we know? J Med Virol. https://doi.org/ 10.1002/jmv. 25766

He J, Hu L, Huang X, Wang C, Zhang Z, Wang Y, Zhang D, Ye W (2020b) Potential of coronavirus 3C-like protease inhibitors for the development of new anti-SARS-CoV-2 drugs: Insights from structures of protease and inhibitors

Henry C, Zaizafoun M, Stock E, Ghamande S, Arroliga AC, White HD (2018) Impact of angiotensin-converting enzyme inhibitors and statins on viral pneumonia. Proc (Bayl Univ Med Cent) 31:419-423. https://doi.org/10. 1080/08998280.2018.1499293

Hosseinzade A, Sadeghi O, Naghdipour Biregani A, Soukhtehzari S, Brandt GS, Esmaillzadeh A (2019) Immunomodulatory effects of flavonoids: possible induction of $\mathrm{T}$ $\mathrm{CD} 4+$ regulatory cells through suppression of mTOR pathway signaling activity. Front Immunol 10:51. https:// doi.org/10.3389/fimmu.2019.00051

Howell AB, D'Souza DH (2013) The pomegranate: effects on bacteria and viruses that influence human health. Evid Based Complement Alternat Med 2013:606212. https:// doi.org/10.1155/2013/606212

Hu JZ, Bai L, Chen D-G, Xu Q-T, Southerland WM (2010) Computational investigation of the anti-HIV activity of Chinese medicinal formula Three-Huang Powder

Huang X, Jiang C, Yu L, Yang A (2020) Current and emerging approaches for studying inter-organelle membrane contact sites. Front Cell Dev Biol 8:195. https://doi.org/10.3389/ fcell.2020.00195

Hyuga S, Hyuga M, Yoshimura M, Amakura Y, Goda Y, Hanawa T (2013) Herbacetin, a constituent of ephedrae herba, suppresses the HGF-induced motility of human breast cancer MDA-MB-231 cells by inhibiting c-Met and Akt phosphorylation. Planta Med 79:1525-1530. https:// doi.org/10.1055/s-0033-1350899

Jeong HJ, Ryu YB, Park S-J, Kim JH, Kwon H-J, Kim JH, Park KH, Rho M-C, Lee WS (2009) Neuraminidase inhibitory activities of flavonols isolated from Rhodiola rosea roots and their in vitro anti-influenza viral activities. Bioorg Med 
Chem 17:6816-6823. https://doi.org/10.1016/j.bmc.2009. 08.036

Jo S, Kim H, Kim S, Shin DH, Kim M-S (2019) Characteristics of flavonoids as potent MERS-CoV 3C-like protease inhibitors. Chem Biol Drug Des 94:2023-2030. https://doi. org/10.1111/cbdd.13604

Jo S, Kim S, Shin DH, Kim M-S (2020) Inhibition of SARSCoV 3CL protease by flavonoids. J Enzyme Inhib Med Chem 35:145-151. https://doi.org/10.1080/14756366. 2019.1690480

Keum Y-S, Jeong Y-J (2012) Development of chemical inhibitors of the SARS coronavirus: viral helicase as a potential target

Kim DW, Seo KH, Curtis-Long MJ, Oh KY, Oh J-W, Cho JK, Lee KH, Park KH (2014) Phenolic phytochemical displaying SARS-CoV papain-like protease inhibition from the seeds of Psoralea corylifolia. J Enzyme Inhib Med Chem 29:59-63. https://doi.org/10.3109/14756366.2012. 753591

Kinker B (2014) Quercetin: a promising treatment for the common cold. J Anc Dis Prev Rem. https://doi.org/10. 4172/2329-8731.1000111

Kuete V, Sandjo LP (2012) Isobavachalcone: an overview. Chin J Integr Med 18:543-547. https://doi.org/10.1007/s11655012-1142-7

Lai C-C, Liu YH, Wang C-Y, Wang Y-H, Hsueh S-C, Yen M-Y, Ko W-C, Hsueh P-R (2020) Asymptomatic carrier state, acute respiratory disease, and pneumonia due to severe acute respiratory syndrome coronavirus 2 (SARS-CoV-2): Facts and myths. J Microbiol Immunol Infect. https://doi. org/10.1016/j.jmii.2020.02.012

Lee C, Lee JM, Lee N-R, Kim D-E, Jeong Y-J, Chong Y (2009) Investigation of the pharmacophore space of severe acute respiratory syndrome coronavirus (SARS-CoV) NTPase/ helicase by dihydroxychromone derivatives. Bioorg Med Chem Lett 19:4538-4541. https://doi.org/10.1016/j.bmcl. 2009.07.009

Lee N-R, Kwon H-M, Park K, Oh S, Jeong Y-J, Kim D-E (2010) Cooperative translocation enhances the unwinding of duplex DNA by SARS coronavirus helicase nsP13. Nucleic Acids Res 38:7626-7636. https://doi.org/10.1093/nar/ gkq647

LeJeune TM, Tsui HY, Parsons LB, Miller GE, Whitted C, Lynch KE, Ramsauer RE, Patel JU, Wyatt JE, Street DS, Adams CB, McPherson B, Tsui HM, Evans JA, Livesay C, Torrenegra RD, Palau VE (2015) Mechanism of action of two flavone isomers targeting cancer cells with varying cell differentiation status. PLoS ONE 10:e0142928. https://doi. org/10.1371/journal.pone.0142928

Letko M, Marzi A, Munster V (2020) Functional assessment of cell entry and receptor usage for SARS-CoV-2 and other lineage B betacoronaviruses. Nat Microbiol. https://doi. org/10.1038/s41564-020-0688-y

Li Y, Yao J, Han C, Yang J, Chaudhry MT, Wang S, Liu H, Yin Y (2016) Quercetin, inflammation and immunity. Nutrients 8:167. https://doi.org/10.3390/nu8030167

Li G, Fan Y, Lai Y, Han T, Li Z, Zhou P, Pan P, Wang W, Hu D, Liu X, Zhang Q, Wu J (2020) Coronavirus infections and immune responses. J Med Virol 92:424-432. https://doi. org/10.1002/jmv.25685
Li BQ, Fu T, Dongyan Y, Mikovits JA, Ruscetti FW, Wang JM (2000) Flavonoid baicalin inhibits HIV-1 infection at the level of viral entry. Biochem Biophys Res Commun 276:534-538. https://doi.org/10.1006/bbrc.2000.3485

Lim H, Min DS, Park H, Kim HP (2018) Flavonoids interfere with NLRP3 inflammasome activation. Toxicol Appl Pharmacol 355:93-102. https://doi.org/10.1016/j.taap. 2018.06.022

Lim YX, Ng YL, Tam JP, Liu DX (2016) Human coronaviruses: a review of virus-host interactions. Diseases. https://doi. org/10.3390/diseases4030026

Lin C-W, Tsai C-H, Tsai F-J, Chen P-J, Lai C-C, Wan L, Chiu $\mathrm{H}-\mathrm{H}$, Lin K-H (2004) Characterization of trans- and ciscleavage activity of the SARS coronavirus 3CLpro protease: basis for the in vitro screening of anti-SARS drugs. FEBS Lett 574:131-137. https://doi.org/10.1016/j.febslet. 2004.08.017

Lin C-W, Tsai F-J, Tsai C-H, Lai C-C, Wan L, Ho T-Y, Hsieh C-C, Chao P-DL (2005) Anti-SARS coronavirus 3C-like protease effects of Isatis indigotica root and plant-derived phenolic compounds. Antiviral Res 68:36-42. https://doi. org/10.1016/j.antiviral.2005.07.002

Lin M-H, Moses DC, Hsieh C-H, Cheng S-C, Chen Y-H, Sun C-Y, Chou C-Y (2018) Disulfiram can inhibit MERS and SARS coronavirus papain-like proteases via different modes. Antiviral Res 150:155-163. https://doi.org/10. 1016/j.antiviral.2017.12.015

Margineanu A, Chan JJ, Kelly DJ, Warren SC, Flatters D, Kumar S, Katan M, Dunsby CW, French PMW (2016) Screening for protein-protein interactions using Förster resonance energy transfer (FRET) and fluorescence lifetime imaging microscopy (FLIM). Sci Rep 6:28186. https://doi.org/10.1038/srep28186

McKee DL, Sternberg A, Stange U, Laufer S, Naujokat C (2020) Candidate drugs against SARS-CoV-2 and COVID-19. Pharmacol Res 157:104859

Mukai R (2018) Prenylation enhances the biological activity of dietary flavonoids by altering their bioavailability. Biosci Biotechnol Biochem 82:207-215. https://doi.org/10.1080/ 09168451.2017.1415750

Nguyen TTH, Woo H-J, Kang H-K, van Nguyen D, Kim Y-M, Kim D-W, Ahn S-A, Xia Y, Kim D (2012) Flavonoidmediated inhibition of SARS coronavirus 3C-like protease expressed in Pichia pastoris. Biotechnol Lett 34:831-838. https://doi.org/10.1007/s10529-011-0845-8

Nijveldt RJ, van Nood E, van Hoorn DE, Boelens PG, van Norren K, van Leeuwen PA (2001) Flavonoids: a review of probable mechanisms of action and potential applications. Am J Clin Nutr 74:418-425. https://doi.org/10.1093/ajcn/ 74.4.418

Nileeka Balasuriya BW, Vasantha Rupasinghe HP (2011) Plant flavonoids as angiotensin converting enzyme inhibitors in regulation of hypertension. FFHD 1:172. https://doi.org/ 10.31989/ffhd.v1i5.132

Panche AN, Diwan AD, Chandra SR (2016) Flavonoids: an overview. J Nutr Sci 5:e47. https://doi.org/10.1017/jns. 2016.41

Pandey KB, Rizvi SI (2009) Plant polyphenols as dietary antioxidants in human health and disease. Oxid Med Cell Longev 2:270-278. https://doi.org/10.4161/oxim.2.5.9498 
Park J-Y, Ko J-A, Kim DW, Kim YM, Kwon H-J, Jeong HJ, Kim CY, Park KH, Lee WS, Ryu YB (2016) Chalcones isolated from Angelica keiskei inhibit cysteine proteases of SARS-CoV. J Enzyme Inhib Med Chem 31:23-30. https:// doi.org/10.3109/14756366.2014.1003215

Park J-Y, Yuk HJ, Ryu HW, Lim SH, Kim KS, Park KH, Ryu YB, Lee WS (2017) Evaluation of polyphenols from Broussonetia papyrifera as coronavirus protease inhibitors. J Enzyme Inhib Med Chem 32:504-515. https://doi.org/10. 1080/14756366.2016.1265519

Park HR, Yoon H, Kim MK, Lee SD, Chong Y (2012) Synthesis and antiviral evaluation of 7-O-arylmethylquercetin derivatives against SARS-associated coronavirus (SCV) and hepatitis C virus (HCV). Arch Pharm Res 35:77-85. https://doi.org/10.1007/s12272-012-0108-9

Péter Zomborszki Z, Kúsz N, Csupor D, Peschel W (2019) Rhodiosin and herbacetin in Rhodiola rosea preparations: additional markers for quality control? Pharm Biol 57:295-305. https://doi.org/10.1080/13880209.2019.1577 460

Pohjala L, Tammela P (2012) Aggregating behavior of phenolic compounds - a source of false bioassay results? Molecules 17:10774-10790. https://doi.org/10.3390/molecules17091 0774

Qiu S-X, Lu Z-Z, Luyengi L, Lee SK, Pezzuto JM, Farnsworth NR, Thompson LU, Fong HHS (1999) Isolation and characterization of flaxseed (Linum usitatissimum) constituents. Pharm Biol 37:1-7. https://doi.org/10.1076/phbi. 37.1.1.6320

Rabaan AA, Al-Ahmed SH, Sah R, Tiwari R, Yatoo MI, Patel SK, Pathak M, Malik YS, Dhama K, Singh KP, BonillaAldana DK, Haque S, Rodriguez-Morales AJ (2020) SARS-CoV-2/COVID-19 and advances in developing potential therapeutics and vaccines to counter this emerging pandemic virus - a review. https://doi.org/10.20944/ preprints202004.0075.v1

Rabi FA, Al Zoubi MS, Kasasbeh GA, Salameh DM, Al-Nasser AD (2020) SARS-CoV-2 and coronavirus disease 2019: what we know so far. Pathogens 9:231. https://doi.org/10. 3390/pathogens9030231

Ratia K, Kilianski A, Baez-Santos YM, Baker SC, Mesecar A (2014) Structural basis for the ubiquitin-linkage specificity and deisgylating activity of SARS-CoV papain-like protease. PLoS Pathog 10:e1004113. https://doi.org/10.1371/ journal.ppat. 1004113

Ryu YB, Jeong HJ, Kim JH, Kim YM, Park J-Y, Kim D, Nguyen TTH, Park S-J, Chang JS, Park KH, Rho M-C, Lee WS (2010) Biflavonoids from Torreya nucifera displaying SARS-CoV 3CL(pro) inhibition. Bioorg Med Chem 18:7940-7947. https://doi.org/10.1016/j.bmc.2010.09.035

Ryu HW, Lee BW, Curtis-Long MJ, Jung S, Ryu YB, Lee WS, Park KH (2010) Polyphenols from Broussonetia papyrifera displaying potent alpha-glucosidase inhibition. J Agric Food Chem 58:202-208. https://doi.org/10.1021/jf90 $3068 \mathrm{k}$

Schwarz S, Wang K, Yu W, Sun B, Schwarz W (2011) Emodin inhibits current through SARS-associated coronavirus 3a protein. Antiviral Res 90:64-69. https://doi.org/10.1016/j. antiviral.2011.02.008

Schwarz S, Sauter D, Wang K, Zhang R, Sun B, Karioti A, Bilia AR, Efferth T, Schwarz W (2014) Kaempferol derivatives as antiviral drugs against the $3 \mathrm{a}$ channel protein of coronavirus. Planta Med 80:177-182. https://doi.org/10.1055/s0033-1360277

Shah A (2020) Novel coronavirus-induced NLRP3 inflammasome activation: a potential drug target in the treatment of COVID-19

Sheahan TP, Sims AC, Graham RL, Menachery VD, Gralinski LE, Case JB, Leist SR, Pyrc K, Feng JY, Trantcheva I, Bannister R, Park Y, Babusis D, Clarke MO, Mackman RL, Spahn JE, Palmiotti CA, Siegel D, Ray AS, Cihlar T, Jordan R, Denison MR, Baric RS (2017) Broad-spectrum antiviral GS-5734 inhibits both epidemic and zoonotic coronaviruses

Sheahan TP, Sims AC, Leist SR, Schäfer A, Won J, Brown AJ, Montgomery SA, Hogg A, Babusis D, Clarke MO, Spahn JE, Bauer L, Sellers S, Porter D, Feng JY, Cihlar T, Jordan R, Denison MR, Baric RS (2020) Comparative therapeutic efficacy of remdesivir and combination lopinavir, ritonavir, and interferon beta against MERS-CoV

Shen G, Huhman D, Lei Z, Snyder J, Sumner LW, Dixon RA (2012) Characterization of an isoflavonoid-specific prenyltransferase from Lupinus albus. Plant Physiol 159:70-80. https://doi.org/10.1104/pp.112.195271

Sierecki E, Giles N, Polinkovsky M, Moustaqil M, Alexandrov K, Gambin Y (2013) A cell-free approach to accelerate the study of protein-protein interactions in vitro. Interface Focus 3:20130018. https://doi.org/10.1098/rsfs.2013.0018

Silverman L, Campbell R, Broach JR (1998) New assay technologies for high-throughput screening. Curr Opin Chem Biol 2:397-403. https://doi.org/10.1016/S1367-5931(98) 80015-X

Singh AP, Wilson T, Kalk AJ, Cheong J, Vorsa N (2009) Isolation of specific cranberry flavonoids for biological activity assessment. Isolation of specific cranberry flavonoids for biological activity assessment

Šmejkal K (2014) Cytotoxic potential of C-prenylated flavonoids

Solnier J, Martin L, Bhakta S, Bucar F (2020) Flavonoids as novel efflux pump inhibitors and antimicrobials against both environmental and pathogenic intracellular mycobacterial species. Molecules. https://doi.org/10.3390/ molecules 25030734

Srinivas NR (2009) Structurally modified 'dietary flavonoids': are these viable drug candidates for chemoprevention? Curr Clin Pharmacol 4:67-70. https://doi.org/10.2174/ 157488409787236065

Sultana B, Anwar F (2008) Flavonols (kaempeferol, quercetin, myricetin) contents of selected fruits, vegetables and medicinal plants

Ur Rashid H, Xu Y, Ahmad N, Muhammad Y, Wang L (2019) Promising anti-inflammatory effects of chalcones via inhibition of cyclooxygenase, prostaglandin E2, inducible $\mathrm{NO}$ synthase and nuclear factor $\mathrm{\kappa b}$ activities. Bioorg Chem 87:335-365. https://doi.org/10.1016/j.bioorg.2019.03.033

Wang T-Y, Li Q, Bi K-S (2018) Bioactive flavonoids in medicinal plants: structure, activity and biological fate. Asian J Pharm Sci 13:12-23. https://doi.org/10.1016/j.ajps. 2017.08.004

Wang X, Yang Z, Su F, Li J, Boadi EO, Chang Y-X, Wang H (2020) Study on structure activity relationship of natural flavonoids against thrombin by molecular docking virtual 
screening combined with activity evaluation in vitro. Molecules. https://doi.org/10.3390/molecules25020422

Wang HK, Xia Y, Yang ZY, Natschke SL, Lee KH (1998) Recent advances in the discovery and development of flavonoids and their analogues as antitumor and anti-HIV agents. Adv Exp Med Biol 439:191-225. https://doi.org/ 10.1007/978-1-4615-5335-9_15

World Health Organization (2020a) Coronavirus disease (COVID-19) Pandemic. https://www.who.int/emergencies/ diseases/novel-coronavirus-2019. Accessed 25 Mar 2020

World Health Organization (2020b) Novel Coronavirus (2019nCoV): Situation Report-1 21 Jan 2020. https://www. who.int/docs/default-source/coronaviruse/situationreports/20200121-sitrep-1-2019-ncov.pdf. Accessed 25 Mar 2020

Wrapp D, Wang N, Corbett KS, Goldsmith JA, Hsieh C-L, Abiona O, Graham BS, McLellan JS (2020) Cryo-EM structure of the 2019-nCoV spike in the prefusion conformation. Science 367:1260-1263. https://doi.org/10.1126/ science.abb2507

Wu X, Qin G, Cheung KK, Cheng KF (1997) New alkaloids from Isatis indigotica. Tetrahedron 53:13323-13328. https://doi.org/10.1016/S0040-4020(97)00846-6

Wu W, Li R, Li X, He J, Jiang S, Liu S, Yang J (2015) Quercetin as an antiviral agent inhibits Influenza A Virus (IAV) entry. Viruses. https://doi.org/10.3390/v8010006

Wu C, Liu Y, Yang Y, Zhang P, Zhong W, Wang Y, Wang Q, Xu Y, Li M, Li X, Zheng M, Chen L, Li H (2020) Analysis of therapeutic targets for SARS-CoV-2 and discovery of potential drugs by computational methods

Xian Y, Zhang J, Bian Z, Zhou H, Zhang Z, Lin Z, Xu H (2020) Bioactive natural compounds against human coronaviruses: a review and perspective. Acta Pharm Sin B. https://doi.org/10.1016/j.apsb.2020.06.002

Xu X, Chen P, Wang J, Feng J, Zhou H, Li X, Zhong W, Hao P (2020) Evolution of the novel coronavirus from the ongoing Wuhan outbreak and modeling of its spike protein for risk of human transmission. Sci China Life Sci 63:457-460. https://doi.org/10.1007/s11427-020-1637-5

Yang Y, Islam MS, Wang J, Li Y, Chen X (2020) Traditional chinese medicine in the treatment of patients infected with 2019-new coronavirus (SARS-CoV-2): a review and perspective. Int J Biol Sci 16:1708-1717. https://doi.org/10. 7150/ijbs. 45538

Yi L, Li Z, Yuan K, Qu X, Chen J, Wang G, Zhang H, Luo H, Zhu L, Jiang P, Chen L, Shen Y, Luo M, Zuo G, Hu J, Duan D, Nie Y, Shi X, Wang W, Han Y, Li T, Liu Y, Ding M, Deng H, Xu X (2004) Small molecules blocking the entry of severe acute respiratory syndrome coronavirus into host cells. J Virol 78:11334-11339. https://doi.org/10.1128/ JVI.78.20.11334-11339.2004

Yu M-S, Lee J, Lee JM, Kim Y, Chin Y-W, Jee J-G, Keum Y-S, Jeong Y-J (2012) Identification of myricetin and scutellarein as novel chemical inhibitors of the SARS coronavirus helicase, nsP13

Yu S, Yan H, Zhang L, Shan M, Chen P, Ding A, Li SFY (2017) A review on the phytochemistry, pharmacology, and pharmacokinetics of amentoflavone, a naturally-occurring biflavonoid

Zakaryan H, Arabyan E, Oo A, Zandi K (2017) Flavonoids: promising natural compounds against viral infections. Arch Virol 162:2539-2551. https://doi.org/10.1007/ s00705-017-3417-y

Zhang XW, Yap YL (2004) Old drugs as lead compounds for a new disease? Binding analysis of SARS coronavirus main proteinase with HIV, psychotic and parasite drugs. Bioorg Med Chem. https://doi.org/10.1016/j.bmc.2004.03.035

Zhao Q, Chen X-Y, Martin C (2016) Scutellaria baicalensis, the golden herb from the garden of Chinese medicinal plants

Zhao J, Yang J, Xie Y (2019) Improvement strategies for the oral bioavailability of poorly water-soluble flavonoids: an overview. Int J Pharm 570:118642. https://doi.org/10. 1016/j.ijpharm.2019.118642

Zhou P, Yang X-L, Wang X-G, Hu B, Zhang L, Zhang W, Si H-R, Zhu Y, Li B, Huang C-L, Chen H-D, Chen J, Luo Y, Guo H, Jiang R-D, Liu M-Q, Chen Y, Shen X-R, Wang X, Zheng X-S, Zhao K, Chen Q-J, Deng F, Liu L-L, Yan B, Zhan F-X, Wang Y-Y, Xiao G-F, Shi Z-L (2020) A pneumonia outbreak associated with a new coronavirus of probable bat origin. Nature 579:270-273. https://doi.org/ 10.1038/s41586-020-2012-7

Zhu N, Zhang D, Wang W, Li X, Yang B, Song J, Zhao X, Huang B, Shi W, Lu R, Niu P, Zhan F, Ma X, Wang D, Xu W, Wu G, Gao GF, Tan W (2020) A novel coronavirus from patients with pneumonia in China, 2019. N Engl J Med 382:727-733. https://doi.org/10.1056/NEJMoa200 1017

Zhuang M, Jiang H, Suzuki Y, Li X, Xiao P, Tanaka T, Ling H, Yang B, Saitoh H, Zhang L, Qin C, Sugamura K, Hattori T (2009) Procyanidins and butanol extract of Cinnamomi Cortex inhibit SARS-CoV infection. Antiviral Res 82:73-81. https://doi.org/10.1016/j.antiviral.2009.02.001

Publisher's Note Springer Nature remains neutral with regard to jurisdictional claims in published maps and institutional affiliations. 